\title{
LA LITERATURA PÚDICA COMO UNA FORMA DE INTERVENCIÓN PÚBLICA: EL DIARIO
}

\section{Virgilio Tortosa}

\author{
Universidad de Alicante
}

Quien se confiesa miente, rehúye la verdadera verdad, la cual es nula o informe, y en general, indistinta. Pues la confidencia siempre piensa en la gloria, en el escándalo, en la excusa, en la propaganda.

Paul Valéry

¿Para quién escribo? Si es para mí, ¿para qué va entonces a la imprenta? $Y$ si es para el lector, ¿por qué finjo dialogar conmigo mismo?

Witold Gombrowicz

Pese a una manifiesta falta de tradición diarística en la literatura española, cuando menos queda reconocido el auge sin precedentes experimentado a lo largo de las últimas décadas. Surgido el diario (íntimo) de manera institucional hacia el siglo XVII, a partir de la reforma religiosa practicada en Inglaterra y Francia, en los siglos posteriores proseguirá su desarrollo sobre todo en estos dos países pioneros, y en menor medida en Suiza, Rusia y EE.UU., hasta acabar siendo aceptado por el corpus literario oficial: las diferentes motivaciones 
que proyectaron sus escritores sobre esta creciente fórmula literaria legitimaron su uso. Su origen se puede rastrear hacia $1800^{1}$ cuando la moda confesional inaugurada por Rousseau y por la exaltación del sentimiento propio de una época pre-romántica se apoderan de la sociedad, pero sobre todo por la necesidad de fundar la «ciencia» del hombre sobre la observación, justo cuando constituye la sensación el origen de todo entendimiento, de acuerdo a la filosofía coetánea. Para Lejeune, el diario comparte con la autobiografía un origen común de desmembramiento - cada cual a su manera de una forma particularizada - de una única escritura memorialista tan en boga en el siglo XVIII, cifrándose su origen de un modo ambiguo y genérico. Una cosa parece ser cierta, y es que la eclosión de esta escritura íntima, junto con la literatura autobiográfica y sus diversas manifestaciones, a partir del llamado pre-romanticismo, provoca una transformación radical en la concepción de la persona (Lejeune, 1971: 64).

Muchos de sus críticos refieren que esta modalidad literaria ha llegado por derecho propio a convertirse o a ser considerada un «género literario», como patentizan Laura Freixas, Nora Catelli o Anna Caballé ${ }^{2}$. Lejos de toda posible matización de un género literario respecto de aquello que no lo es, simplemente reseñar que nos parece interesada esta apropiación por los diversos estudiosos cuando la etiqueta no da lugar; en ese sentido Philippe Lejeune (1996: 75). al hablar de su relación práctica con los diarios, por esta vez como escritor de ellos, de entrada descarta cualquier tipo de reglas ya no sólo en el interior del mismo, sino entre éste y otros discursos cercanos: «y las reglas que me he impuesto han borrado por fin la antinomia entre diario y autobiografía...», al ser una forma de escritura que precisamente se caracteriza por deglutir y absorber el resto de manifestaciones discursivas para asimilarlas y apropiárselas, trocar conforme asimila, y cambiar sus formas de

1 Barthes, en cambio, en una breve alusión, cifra su inicio en Francia durante el XVI: «en el siglo XVI, cuando se empezaron a escribir, se les llamaba, sin reticencia, diaire (diarios)» (Barthes, 1975: 104).

2 En palabras propias, respectivamente: «hasta convertirse en un género literario, trabajado como tal, por escritores» (Freixas, 1996: 5); «Por eso no creo que sea casualidad que el «diario íntimo», como género literario, haya empezado a existir en esa misma época» (Catelli, 1996: 94); «Disponemos de muy pocos estudios en profundidad acerca de la naturaleza y desarrollo de este género en España» (Caballé, 1996: 105). Por su parte, el editor del monográfico al que remiten todos estos artículos sobre el diario ha publicado un fragmento del autor considerado pionero teórico de esta forma de escritura, Alain Girard, quien en una temprana fecha publicó el libro considerado punto de partida en la teoría, Le journal intime, en versión abreviada de la introducción bajo el significativo título de «El diario como género literario». 
manera permanente. ¿Acaso no sea ésa la motivación de ese corpus que llamamos literatura a lo largo de todos los tiempos?

Si hacemos caso de los datos que aporta Laura Freixas, la producción de diarios íntimos en España en el siglo XX atiende poco a la introspección personal y en mayor grado lo hace a la historia y justificación política de su autor, casi nunca hacia la indagación moral, sicológica o incluso la cotidianeidad individual sino más bien como crónica costumbrista. Como quiera que sea, con el advenimiento del siglo $\mathrm{XX}$ las cosas empiezan a cambiar con unas producciones textuales que, a juicio de la crítica más autorizada, ostentan el título legítimo de diarios por primera vez en la literatura española. Los hay que pretenden ver, en la expansión del diario entre los escritores y pensadores a lo largo del siglo XX, la toma de conciencia de la importancia de la experiencia en los procesos históricos: «Han traducido a conceptos la imagen de la persona, tal como se encuentra expresada de modo difuso en los diarios íntimos del siglo XIX» (Girard, 1996: 34). De ese modo, el desarrollo experimentado de forma masiva por el diario a fines del XIX es consecuencia de las transformaciones habidas con el advenimiento de la revolución industrial, donde el nuevo individuo queda modificado en su relación con la sociedad que le ampara ${ }^{3}$. Para Caballé el valor del diario español a lo largo de su escasa existencia documentada reside en constatar de un modo vago opiniones y generalizaciones sobre el carácter español con comentarios impresionistas difusos y ocultos. Muchos escritores utilizan este vehículo escritural en tanto hilo conductor de la cultura a través de los cuales hilvanan sus reflexiones personales como sería el caso actual de Gimferrer o Trapiello. Generalmente sirven para vislumbrar no ya la carga intelectual de los personajes representados sino los modos personales de entender el mundo que los envuelve de la forma en que ocurre en los casos de Manuel Azaña, Josep Pla, Dionisio Ridruejo, o el caso más cercano entre nosotros de Francisco Umbral (Caballé, 1996: 103 y 105).

Si bien secreto en los siglos precedentes, hoy constituye una práctica pública o cuando menos árduamente publicitada, dado que el

${ }^{3}$ En palabras de Girard (1996: 35): «Si el individuo se interroga con tanta avidez sobre sí mismo, es porque su situación se tambalea y necesita encontrar las bases de un nuevo equilibrio. No es seguro que las haya encontrado todavía hoy, pero es indudable que el diario íntimo, en tanto que género practicado y reconocido, expresa la interrogación del individuo frente a su nueva posición en el mundo. En este sentido aparece como un rasgo característico de una sociedad, como síntoma de una época de transición.» 
concepto de intimidad - pilar básico del diario, a decir de la crítica teórica, aun a pesar de su discutibilidad - ha cambiado totalmente, pero también el hecho de que el diario - a diferencia de antaño- se escribe con la pretensión de publicarlo, además en vida del propio escritor (hecho que fue impensable en otras épocas), con el agravante añadido de hacerlo al poco tiempo de haber sido escrito, como nos demuestran las constantes publicaciones al respecto de Andrés Trapiello y J. L. García Martín, por poner unos ejemplos. Freixas también ofrece la clave de la masificación del diario en la actualidad, clave por otra parte de la que participa la coartada televisiva de nuestras pantallas diarias al afirmar que

la literatura española ha llegado al diario íntimo en un momento en que el concepto de intimidad, y el género literario que supuestamente la encarna, han sido desnaturalizados: el diario intimo ha dejado de ser secreto, lo que hace tramposa o dificil la expresión de la intimidad en él, y paralelamente la intimidad misma se rebaja, en ciertos medios de comunicación, al rango de exhibicionismo (Freixas, 1996: 14).

A ello añadimos otras causas que apoyan su auge como es el desarrollo de cierta producción teórica especialmente referida a modalidades escriturales transversales y cercanas al diario como son la autobiografía o las memorias en las que participa éste; muchas de esas aportaciones teóricas vienen apadrinadas del exterior o simplemente vertidas en traducciones oportunas o tesis que dan cuenta de una bibliografía en ciernes, y de las que hoy se hace eco el mercado español de una forma más normalizada.

Del auge del diario en tanto producción literaria nos pone sobre la pista Philippe Lejeune al explicarnos cómo el severo proceso de escolarización, sufrido en las sociedades occidentales y que engloba a la práctica totalidad de la población, supone el factor que en mayor medida explicaría este auge contrastado respecto a antaño, cuando el grado de escolarización básica y el analfabetismo hacían impropia la participación de los ciudadanos: ésta es la forma más asequible de acceso a la escritura que tiene cualquier persona con un mínimo de inquietudes -no necesariamente literarias-, e incluso proceso de aprendizaje y superacion para quienes son escritores «profesionales». No olvidemos que muchos de los diarios (impublicados por su anonimato) surgen con la motivación de la necesidad profesional de periodizar como ocurre en las facetas de la salud, los negocios, las recetas culinarias, los viajes... Lejeune patentiza con un ejemplo gráfico el modo en que 
afecta esta forma de escritura — dadas sus características- a los adolescentes entre cuyas filas militan adeptos muy avezados ${ }^{4}$.

Si la transición española ha producido la conquista de valores como el ámbito íntimo o privado, ello ha sido efectivo a costa del sacrificio de otros distintos (Mainer, 1994: 154): el desarrollo del individualismo en la medida en que una doctrina desplazada desde la dinámica económica hacia la social ha acabado por contaminar parcelas como la cultural en forma de una «reprivatización» del discurso literario que resulta válida tanto al autor como al sufrido lector. La posesión física ahora es una ley que se extiende más allá de la vida económica, lo que traducido en el campo de la literatura se manifiesta bajo la sintomatología de una proliferación abundante de diarios, dietarios y memorias personales. El diario es un fórmula para épocas de incertidumbre en las que los refugios individuales cobran mayor importancia: cuando todo es incierto alrededor (la vida insegura en diferentes aspectos), la potestad del yo busca como sustento una escritura que se permita el capricho de la arbitrariedad. De ahí la conclusión más palpable a la que llega J.-C. Mainer sobre la proliferación de este tipo de escritura durante la transición y su arraigo en la actualidad de las letras hispánicas, al apego de la fechación de documentos entre los propios escritores, es decir, la evidencia de que el diario supone una forma más de reprivatización del ámbito literario; incluso sus productores se entregan a él haciendo patente el orgullo de vivir por y para la literatura (como si se tratara de la torre de marfil de los poetas finiseculares ya distantes en el tiempo). En 1963 Alain Girard (1996: 31) explicaba la extensión de esta modalidad en palabras que semejaban proféticas: «la forma del diario ha adquirido una singular expansión. No sólo se publican los diarios de los autores del siglo pasado, o nuevas ediciones más completas, sino que numerosos escritores publican su propio diario o fragmentos del mismo». En todo caso, la adopción de nuevas

4 En el citado artículo, Lejeune cuenta minuciosamente en primicia al lector español el origen de sus investigaciones en el campo del diario, tras varias décadas de dedicación exclusiva a la autobiografía. Lo que empezó como simple curiosidad en una charla con una colega también profesora, acabó convirtiéndose en un riguroso método de investigación que desveló con las oportunas encuestas entre estudiantes de diversos ciclos y sondeos, a través de anuncios en prensa, cómo el diario no sólo no era una escritura en desuso sino que seguía más viva que nunca, sobre todo entre los adolescentes por adaptarse su forma de expresión a las características de esta fase de la vida: «Mucha gente se imagina que llevar un diario es una costumbre pasada de moda, que ha caído en desuso. Yo sostengo la hipótesis inversa: la práctica del diario está ligada a la escolarización de los adolescentes. La escuela obligatoria para todos, y la prolongación de los estudios, no han podido sino desarrollarla» (Lejeune, 1996: 61). 
formas de concepción del diario íntimo ha acarreado un cambio radical del estatuto canónico al que se acogía primigeniamente, con la consiguiente evolución hacia otras formas más coetáneas tras su explotación en forma de publicación masiva de los mismos y la impregnación de un carácter público, resituándolo de nuevo en el seno de la literatura y de las historias de estas formas de expresión ${ }^{5}$.

Laura Freixas nos advierte, siguiendo a Alain Girard, las diferencias entre lo que llamamos diario en sí, es decir, cualquier escrito con las características que en adelante otorgaremos, diario íntimo y dietario tal y como hacen los anteriores críticos. Según Freixas en el diario íntimo predomina lo afectivo, se presenta fechado y enraizado en la vida cotidiana; en el dietario - término divulgado en nuestro ámbito merced a Josep Pla- predomina lo intelectual, es intemporal y alude a las circunstancias más bien de trama meditativa o sojuzgadora. Pere Gimferrer es el más importante de los divulgadores en nuestro ámbito con dos Dietaris que no tienen entre sus objetivos la frivolidad o la intimidad de su autor, sino todo lo contrario. Mainer (1994: 155) nos pone sobre la pista de esta forma de escritura: «no ha escrito sus dos excepcionales Dietaris para narrar sobre fechas tan necesitadas de olvido sino cuando, entre 1979 y 1982, era ya una obligada referencia de la vida cultural catalana y uno de los directores editoriales más influyentes del mundo hispánico». Al margen de que la cita por sí misma sea capaz de resumir las diferencias esenciales entre diarios y dietarios, no es de nuestro interés matizar diferencias ni acotar lo que ya de por sí resulta harto complicado, sino más bien pretendemos abarcar la producción de diarios - de modo genéricoen el período objeto de estudio, sin una necesidad de trazar fronteras o encasillamientos estancos - para el fin que nos proponemosentre dietarios o diarios íntimos respecto a diarios en sí, por cuanto lo que nos interesa de esta producción discursiva no son tanto sus fisuras internas como su configuración, y las pretensiones que tiene entre los diferentes escritores que la usan para generar un sujeto que represente al ser humano en el final de siglo. Bien que la práctica mayoría de cuantos críticos autorizados se han acercado a estudiar el «diario»

5 Caballé (1995: 55) se expresa del siguiente modo: «Si en teoría el diario íntimo debería reflejar la subversión expresiva de los vaivenes del alma, en la práctica, las cosas cambiaron mucho para el auténtico diario cuando éste pasó de un estatus privado, connatural, a un estatus público; supuso un acontecimiento importante, tanto desde el punto de vista de la historia de las formas literarias como desde una perspectiva ontológica de la literatura». 
lo han hecho en tanto «diario íntimo», y muchos ven lo uno indisoluble de lo otro, nosotros preferimos su denominación genérica, pues defendemos un concepto de diario como forma de literatura que trasciende toda clase de privacidad, y que lejos de circunscribirse esta forma de escritura yoica concreta al ámbito reducido de lo púdico o personal, subjetivo o intransferible, doméstico o secreto, como quiera que sea, nuestra tesis es que ésta - la íntima - es una forma más, como cualquier otra, de manifestación escritural, y que daría cuenta de las expresiones más recónditas del individuo (poseyendo su legitimidad siempre en su manera de uso), pero no la única como parece ser la constante e incluso lo obvio, tras leer toda esa literatura crítica existente al respecto. Lo que sí nos importa, por lo tanto, es la ficcionalización de ese «yo» 6 inserto en los diferentes textos que en adelante abordaremos, y por tanto nos interesan sobre todo y en especial los diarios ficticios o literarios, es decir, aquellos sometidos a un proceso de literaturización, bien que no reneguemos en ningún momento del diario referencial propiamente dicho, con el que apoyaremos ciertas explicaciones. En ese sentido matizar que el diario es una convención (más), dada su imposibilidad referencial de registrar todos - absolutamente todos- y cada uno de los hechos acaecidos a la persona que se somete a la arbitrariedad del registro escritural mediante el acto convencional de la escritura de su vida, puesto que el fin último del diario sería una obsesión imposible de cumplir, de acuerdo al propósito íntegro de esta forma de escritura y el deseo de sus escritores por registrar fehacientemente todos los hechos de una vida periodizada por parcelas que abarcan lo que el ciclo terrestre, ya que vivir para registrar escrituralmente todo cuanto nos acaece, además de imposible - y proceso que nos llevaría a una neurosis obsesiva--, es un sin sentido de conclusión nada rentable, mucha que sea la disposición temporal de una persona para ese menester; pues aun siendo toda la del mundo resulta imposible registrar cuanto nos conforma en acción, pensamiento o percepciones, además de obstinación innecesaria si no hay una experiencia vital detrás; pero, caso de haberla, las necesidades de registrarla la convertirían en tarea imposible: no olvidemos que toda creación artística siempre actúa por simplificación y estilización, representación todo lo más. En el seno de esta paradoja queda atrapada la

6 En ese sentido Caballé da cuenta de la importancia de todo ese material acumulado por muchos escritores cuando en algún momento de su vida sirve como material de base para la consecución de sus propias obras: «es muy frecuente que tanto la literatura de ficción como la de no ficción se apoye en un material de trabajo recogido en diarios que ayuden a la reconstrucción de lo que se pretende» (Caballé, 1995: 57). 
escritura de los diarios. Con lo cual deducimos que esa imposibilidad marca una de las reglas capitales de esta manifestación escritural como es su arbitrariedad registrada por la subjetividad de quien se enfrenta a expresar sus propias vivencias por escrito, además de un necesario proceso selectivo que valide el material: la azarosidad de la máquina cerebral, añadido a la complejidad de los procesos psíquicos y el estar jugando de continuo con los sentimientos íntimos de quien se somete al juego, ponen sobre la pista de la aleatoriedad en los procesos de selección de unos pensamientos sobre otros que finalmente vencerán en el papel. Existe una operación siempre selectiva en la mirada del escritor que lo conduce a la cercanía de lo accidental, anecdótico y meramente contingente, donde cualquier indicio por inexplicable que sea puede reconducir la argumentación sin regreso anhelado al punto de origen ni explicación oportuna, sin una estructura predeterminada o concepción previa: la preferencia, los gustos, las subjetividades y el grado de impudor marcan la tónica y -cuando menos diríamos que- son su hilo conductor ${ }^{7}$.

El diario está marcado por una compleja red de características que lo atraviesan hasta el punto de ser éstas siempre selectivas y no inclusivas, pero también participa de otras modalidades escriturales o formas discursivas amalgamadoras que lo enriquecen, con lo cual la primera deducción más plausible que sacamos es la imposibilidad de su definición ante esa capacidad camaleónica de constituirse en una escritura escurridiza, sin límites ${ }^{8}$. Aun así sentimos la tentación de intentar dar cuenta de los fenómenos que se dan cita en el diario y, empezando por el principio, el punto de partida sería la capacidad de fechar la escritura: el diario, del mismo modo que el periódico, tiene su origen e idiosincrasia en el día a día (de una marcada temporalidad) con que es fechada la escritura; en ambos, el acontecimiento debe ser registrado sin distancia alguna que permita cualquier reelaboración del recuerdo o reconstrucción de hechos a posteriori. Por tanto, esa escritura del día a día será, sin objeción alguna, fragmentaria, sin una concepción de obra propiamente dicha con límites establecidos ni sentimiento alguno de acabamiento, con lo cual su funcionamiento lo acerca más al ejercicio literario o banco de pruebas de

7 Una maleabilidad expresada por Muñoz Millanes (1996: 137) en los siguientes términos: «así efectúa una lectura fetichista de la realidad, es decir, arbitrariamente parcial».

${ }^{8}$ Un saco sin fondo de la escritura: «Desde el momento en que el diario deja de encerrarse en el discurso introspectivo únicamente, se vuelve el receptáculo de todos los tipos de escritura, prácticamente sin límite» (Didier, 1996: 39). 
la cotidianeidad que del rigor de la obra literaria, dado que la premura del papel fechado dificulta la tarea de repensar y reelaborar los propios escritos ${ }^{9}$. Si bien no podemos ocultar la ejemplaridad de cuantas obras literarias ficticias se hallan estructuradas a partir del diario de un modo ejemplar, Nora Catelli nos ofrece una definición de diario que, como punto de partida, así ofrecemos sin crear la falsa ilusión en ningún momento de contentar el ánimo de nuestras pesquisas: «el diario es el género en el que se registran, siguiendo los días, las actividades e impresiones de un sujeto frente a sí mismo» (Catelli, 1996: 87). Al margen de un uso dudoso y clasificatorio de «género» que deberíamos definir, creemos - por lo antes dicho- que puede ser muchas otras cosas a la vez, e incluso diferentes a la definición dada. Enric Bou (1996: 124), por su parte, dirá que el «diario es una crónica cotidiana, escrita desde el presente, de una experiencia personal». Para Laura Freixas el diario atiende a dos lógicas ineludibles: estar fechado y obedecer a una cierta cotidianeidad de los hechos narrados o intimidad. De ahí que quien está considerado en nuestra literatura como uno de los primeros diaristas, Unamuno, no lo sea según los criterios de Freixas ${ }^{10}$. En consecuencia, la correspondencia, de la misma manera que el diario, no tiene una estructura establecida sino que, todo lo contrario, constituye en material lo informal sin adaptarse de ninguno de los modos al flujo de la consciencia huidiza mediante una convencionalidad de reglas formales o retóricas que aquí resultan cambiantes (Marí, 1994: 115). Aun poniendo José Muñoz Millanes (1996: 145) en boca de Peter Handke la capacidad del diario de introspeccionar la cotidianeidad y de sobrellevar con su ayuda el peso de la historia al brindarle «un simulacro de normalidad cotidiana o natural», planteado de ese modo el problema, se puede incurrir en una fácil desresponsabilización y un desapego incongruente de los procesos históricos en curso ${ }^{11}$, pues la realidad también se construye desde

9 Muy agudamente reconoce Didier (1996) que el diario tal y como fuera conocido en el XIX y en la primera mitad del XX no parece ya posible por cuanto la noción de individuo ha cambiado radicalmente, pero reconoce muchas posibilidades en la modalidad literaria del diario al incorporar en su lecho técnicas narrativas de lo que supone una apropiación.

10 Ésta dice de él: «Entre 1897 y 1902 Unamuno apunta en un cuaderno algunas meditaciones doloridas: publicadas en 1970 bajo el título -escogido por los editores-Diario íntimo, nos ofrecen un ejemplo opuesto a los anteriores: es un texto íntimo, pero no es un diario» (Freixas, 1996: 6-7).

${ }_{11}$ «Pues en tanto que fetichista, el escritor de diarios se aferra a los detalles como un mecanismo de defensa: retira la atención hasta su periferia a fin de amortiguar el impacto de un drama histórico», aclara Muñoz Millanes (1996: 146). 
el polo opuesto, la presencia de una cotidianeidad que confirma el proceso histórico.

Esa crónica cotidiana escrita desde el presente nos lleva a otra característica de esta modalidad que es lo que Enric Bou (1996: 126) llama texto escrito «in media res acerca de uno mismo y para uno mismo». La escritura ejercida en y desde el momento del presente con atención virada hacia el pasado cuando menos siempre inmediato (y no del todo acabado; es más, se da por aceptada la casi coincidencia del acto de escritura con lo vivido y anotado: lo que ha sido escrito ha tenido pretensiones de una existencia referencial horas/minutos antes) y la primacía de un «yo» problematizado que se somete a esa reflexión instantánea serán las constataciones textuales más palpables. Pero la construcción textual produce entre sus efectos la no linealidad, una desorganización del material y una construcción en forma de collage, además de reiteraciones inevitables, pero también la carencia de criterios a posteriori que determinen un punto de vista retrospectivo sobre el que se construya y estructure el relato ${ }^{12}$, una minuciosidad frecuente en lo descrito, y bosquejos sin mayor pretensión de acabamiento donde a veces el intimismo juega la mala pasada de hablar en cierta clave sólo adivinable para quien la construye o su entorno inmediato (Bou, 1996: 126). Es una escritura que se presenta a retazos, obligada a la fragmentación o atomización que impone el calendario, organizada por instantáneas de la vida misma, imprimiendo su autor un efecto al texto de «estado trunco» (Bou, 1996: 127) siempre patente: por lo tanto es el lugar de confluencia de prácticas discursivas opuestas ${ }^{13}$, y aun adoptando las más de las veces el estilo narrativo, ello no siempre es así (o mejor dicho

12 Esta desorganicidad textual expandida en sus diversos niveles lleva a Pope a cifrar las características más importantes del diario en los siguientes términos: «El escritor de un diario, a pesar de que anota hechos de su vida, no puede visualizar la importancia que ellos adquirirán en el transcurso de su existencia y carece de la posibilidad de estructurarlos para presentar una imagen coherente de su persona. Se ocupa, generalmente, de sólo un período, en el cual el ocio o el interés incitan a su autor a que deje constancia de las acciones del día para más tarde abandonar la empresa acaso cuando sus actividades se tornan más urgentes e interesantes. Repetición, falta de equilibro, una ausencia de relación entre el detalle con que se trata un asunto y la importancia de él, son elementos frecuentes del diario" (Pope, 1974: 3).

${ }_{13}$ Bou refiere las características más destacadas de esta discursividad: «...quien escribe un diario se interesa por anotar los hechos de cada día, personales, familiares, literarios, político-sociales. Necesita el diario de unas mínimas condiciones: anotaciones periódicas, atención hacia lo inmediato, entidad literaria. Se caracteriza también por la monotonía, la repetición de días, con sus gestos y acciones, visitas, conversaciones, lecturas. Tres elementos son fundamentales: el narrador escribe en primera persona, acerca de sí mismo; escribe sobre la realidad diaria, con un dominio claro del presente en que se produce la escritura, sin acceso al futuro; produce un informe escrito que, evidentemente, decide publicar. Este paso es fundamental, puesto que la publicación afecta de 
deja de serlo a veces). El punto de vista es múltiple e incluso contradictorio (Caballé, 1995: 53).

En el diario también formarán parte de su composición, además de las alusiones temporales, atemporalidades como las reflexiones, las ideas, las sensaciones, los sentimientos, las descripciones o las discusiones bien que sean de uno mismo; a veces adoptará formas de relato de encuentros o desencuentros, conversaciones personales o lecturas que aporten algo decisivo a lo que es la formación del escritor y las presuntas estéticas adoptadas por quien firma el libro. En el diario, la preocupación se centra en hacer referencia al paisaje, clima (al estar estrechamente unido con la temporalidad y con los ciclos temporales), hábitos y hábitat (comidas, paseos), objetos familiares o demás circunstancias que embadurnan la vida cotidiana donde se refleje la relación del diarista con su entorno pero también a veces modificando hábilmente la impresión por la reflexión ${ }^{14}$. Por contra, entre los peligros advertidos que acarrea la propia idiosincrasia de esta escritura, Didier nos pone sobre aviso de lo monódica que puede llegar a ser a veces, incluso alcanzando lo asfixiante de su discursividad. Es una escritura que puede fácilmente hacerse endogámica y difícilmente reconciliable con los moldes preestablecidos que tenemos de literatura al uso. A diferencia del carácter sintético que posee la escritura autobiográfica, el diario presenta un carácter analítico de la vida individual (Neuman, 1970: 59), por cuanto en la autobiografía el hilo estructural es el retroceso que efectúa la memoria para ordenar un material pretérito mientras que el diario atiende a la fragmentariedad por no existir el condicionante de la memoria al ser acciones que acaban de acaecer, las cuales suelen estar dadas a la reflexión con tal de que puedan componer un sentido con esa escritura (Melo Miranda, 1987: 34). En el diario quien se contempla -en la cercanía- se comprende a partir del momento en sí, pero en la autobiografía el hombre se ve «históricamente» al mirar en la distancia ( «La autobiografía es tranquila, el diario excitado, etc.» [Neuman, 1970: 59]). Mientras que

manera precisa a la condición íntima y privada del diario. Del lector único, de la sinceridad «auténtica», pasamos a la sinceridad «manipulada», de cara a un público. Nunca sabremos cuánto de ese diario ha sido suprimido, reescrito» (Bou, 1996: 124-5).

14 Anna Caballé por su parte cifra las siguientes características en el diario: «el diario está libre de acción, de contexto, de limitaciones de estilo. Nada lo sujeta, en efecto, como no sea la necesidad interior de hallar un punto de amarre. Lugar de repliegue, de confinamiento, de preservación del yo, el diario se erige como un espacio privilegiado para exprimir ese indefinible malestar que atenaza el ánimo y «"arrojarlo por la borda"» (Caballé, 1995: 56). 
el diario se compone de interpretaciones momentáneas de la vida con absoluta fidelidad, en la autobiografía el pasado está subordinado a una visión desde el presente (Weintraub, 1991: 21). Por lo general las memorias y la autobiografía manipulan los complejos mecanismos de la memoria con el oportuno distanciamiento que impone la «línea incierta del futuro» (Caballé, 1995: 52), mientras que el diario ya no maneja los recuerdos sino las impresiones causadas por las acciones que todavía conservan su impronta prolongada en el momento de la escritura por su conexión inmediata. Lejeune marca una diferencia tajante entre diario íntimo y autobiografía; mientras la autobiografía se erige en «relato retrospectivo y global» (Lejeune, 1971: 34), con tendencia a la síntesis, el diario íntimo es una escritura prácticamente contemporánea y fragmentaria sin ninguna forma fijada por patrones estrictos; todo lo contrario más bien, es una actividad literaria altamente convencionalizada y aceptada por reglas pero que resultan muy maleables. La autobiografía tiene capacidad de organizar su relato de modo que aparezca el tiempo de la escritura generando una tensión predominantemente entre el presente y el pasado a lo largo del mismo, frente al diario donde coincide - por lo general- el tiempo del relato con el de la narración. Pero la autobiografía puede adoptar formas experimentales como la de revivir el pasado a través de la inserción de fragmentos pasados de diario íntimo, con lo cual se complica la forma estándar. Mientras la autobiografía funda su proyecto con uno mismo, el diario posee el carácter de «perpetuo comienzo» donde todo podrá ser rehecho. La autobiografía confiere una forma definitiva al pasado, difícilmente recomponible en otros sentidos; el diario es provisional y se escribe conforme su marcha (Lejeune, 1971: 36). El diario íntimo atiende a una supuesta precisión y exactitud en los datos vertidos de manera inmediata de tal modo que la técnica retrospectiva de la autobiografía se ve frustrada en su intento mucho que lo pretenda (May, 1979: 151): es más, los fantasmas de esta aproximación son los que definen su particularidad, bien que a veces se impregnan de estas técnicas narrativas para intentar precisamente ficcionalizar las vivencias.

En principio, todo aquel que se somete a la escritura de un diario pretende establecer su identidad más oculta, si bien el yo «real» buscado se convierte en una «ilusión referencial inalcanzable» (Bou, 1996: 127). En la escritura de un diario interviene un «yo» del narrador-protagonista fruto del desdoblamiento practicado por el autor en un «yo-él». Elementos como personaje, protagonista y narrador a un mismo tiempo quedan subordinados al arbitrio de los hechos de la vida real. El hecho de que el narrador explique su propia historia en prime- 
ra persona implica que el autor sea al mismo tiempo sujeto y objeto de la acción (lo que Genette considera simultáneamente una narración homodiegética y autodiegética [véase 1991: 64 y ss.]), es decir, se «crea un falso juego de reflejos, como de desdoblamiento» (Bou, 1996: 127).

Toda actuación humana no es más que representación de un yo que adopta esa fórmula empírica para ser aprehendida mentalmente: construimos un yo del otro como imagen mental para poder hacernos lugar de ese yo propio que convive con nosotros. El sujeto es quien construye ese yo para cada actuación, recuperado o restaurado en el papel; pero además de construir, vigila y controla, lo rectifica en el curso de su actuación, e incluso si lo ve necesario lo transforma de tal modo que se ajuste a unas necesidades virtuales donde ese sujeto encaje lo mejor posible: «el yo, cada yo, es un instrumento del sujeto, que éste dispone para una actuación» (Castilla del Pino, 1996: 17). El psiquiatra diferencia a las claras en la representación de actuaciones íntimas la verbalización respecto a la mostración de lo imaginado, otorgándole su auténtico sentido al primero por cuanto lo íntimo podrá decirse pero no mostrarse, de ahí que esta escritura pueda mentir: lo que se dice acerca de lo pensado, imaginado, deseado... no puede corresponder con lo que fue pensado, imaginado, ejecutado (Castilla del Pino, 1996: 19); pero lleva a cabo la escenificación de las actuaciones íntimas. Éste habla de un pacto establecido entre el sujeto y un «yo», es decir, con nosotros mismos (1996: 20) para tales efectos. La dinámica de la intimidad en un proceso de socialización necesita de una actuación privada y verbal referida a esas actuaciones íntimas que resultan ser la confidencia practicada con un interlocutor especial, llámese ese otro «yo» como se quiera: «La intimidad es un espacio reservado, una «reserva», y además un «espacio protegido» en donde se conservan las más raras especies de yos y, por tanto, del comportamiento humano, la mayor parte de las veces insospechado para los demás» (Castilla del Pino, 1996: 24). Siguiendo con la opinión de este autorizado estudioso de los comportamientos mentales en la escritura, la intimidad es pasto incluso del poder, por inmiscuirse con frecuencia en ese reducto de sujetos disfrazados de diversas maneras (1996: 25) bien que también le reconoce una capacidad defensiva contra el poder, una manera de protegerse - los diversos yoes- del control externo. Por ello, la intimidad se construye de continuo en todas las sociedades y en todos los momentos y regímenes. Su grado extremo y peligroso, refiere, es el ensimismamiento que llega a posiciones de aislamiento absoluto del sujeto. En el caso de la literatura, el uso de la intimidad nos viene dado 
por modos y fenómenos externos como el redescubrimiento folletinesco del interior del ser humano en discursos plurales como la telenovela, usos y costumbres practicadas en la sociedad contemporánea. El origen de la conciencia de uno mismo y la estima practicada hacia la propia persona están ligadas a la dignidad que se le otorga a un nombre y su prestigio social asumido en un determinado momento. De ahí que gran parte de quienes se someten a este tipo de escritura $y$, sobre todo, la publiquen sean escritores, intelectuales, políticos y personajes públicos de cierta relevancia y aceptados en unas determinadas sociedades. Por otra parte, en otro sentido de la brecha, la interiorización practicada por el individuo, según Nora Catelli, nos demuestra, a poco que se estudie en la cadena diacrónica de los diarios publicados, que es el resultado de un proceso histórico que lo moldea:

\begin{abstract}
Esa interiorización es resultado de un proceso histórico: se produce al adquirirse conciencia de que los demonios que la religión mostraba amenazantes, pero otros, distintos a nosotros mismos, han penetrado el círculo reservado a lo propio, se han convertido en parte de "uno mismo". Se han fundido con la conciencia, se han hecho uno con el sujeto (Catelli, 1996: 93).
\end{abstract}

Además de ese proceso histórico moldeado según las necesidades de cada momento que generalmente coinciden con las de las clases dirigentes, en nuestra sociedad actual la práctica cotidiana de los diversos y amplios discursos que circulan - desde la televisión hasta la publicidad, desde el cine hasta la informática... - han adoptado de forma masiva la comunicación privada de experiencias (íntimas) toda vez que han impuesto una concepción del mundo estructurada en forma de mosaicos o fragmentos emotivos continuados ${ }^{15}$. Es lo que Mainer llama la imposición de una corriente reprivatizadora que se ha hecho fuerte en la vida cotidiana. En la fase del capitalismo en que nos hallamos, ésta parece ser la manera correlativa de formular la vanidad personal de los propios escritores, la gloria social, el orgullo y la condición de autor en consonancia con la ideología impuesta por los mecanismos de este sistema, donde la intimidad ha despegado de su

15 Esta radiografía a los usos verbales de la sociedad actual, en palabras de Mainer tiene las siguientes manifestaciones: «Todo se ha convertido en comunicación privada de experiencias y, a la vez, se ha impuesto una concepción del mundo que quiere verlo como una reunión de fragmentos emotivos, un álbum de sorpresas y reminiscencias. Incluso el arte de las memorias se ha contaminado de tales características. Y han dejado de ser, como lo eran, una forma de leerse uno mismo por un modo de coherencia autojustificatoria que la dispersión de lo vivido difícilmente proporciona» (Mainer, 1994: 160). 
valor original y reductor para adoptar otros más en consonancia con la sociedad impúdica y exhibicionista que vivimos: la vida privada ha sido asumida por los medios de comunicación hasta el punto de verse inmiscuida de continuo por todos los lugares de la cosa pública ${ }^{16}$. Esta marea creciente de diarios, bajo una mayor difusión de la intimidad y del carácter privado de las vidas, manifiesta un cambio profundo en la antigua concepción que las personas tenían de sí mismas (Girard, 1996: 32). A partir de cuando el diarista considera no sólo la posibilidad de publicarlo sino que tiene la conciencia certera o evidencia de su publicación posterior al momento de la redacción, altera por completo la sustancia que lo motiva, «se vuelve susceptible de registros completamente diferentes y que en principio parecían resultarle ajenos» (Didier, 1996: 41).

Por último a este respecto, retomando la ingrata cuestión de la tipología, sin sentirnos tentados ni con mucho atados a una necesidad de afinar en las clasificaciones, al menos mentar que, según el tipo de destinatario, el diario puede ser privado (cuando el lector es el propio escritor, controlador o «editor», si se quiere de los papeles, caso de que desee que salgan a la luz), y público (publicado normalmente en la prensa con un destinatario amplio, desconocido, pero destinado desde un inicio a la imprenta). Desde luego que ambos valores resultan mucho más complejos a poco que uno se acerque a cada cual para esclarecer dudas, puesto que todo diario, al ser escrito, difícilmente se podría afirmar que su autor, por mucho que sea el pudor y el recelo con que lo haya escrito a lo largo de las horas, días, meses, años, lo hace por un simple placer, ejercicio personal o confidencia estricta que muere en lo personal de su hazaña, dado su carácter confesional e introspectivo. Aquí queremos pensar que la motivación de un diario puede ser múltiple, pudiéndose dar tangencialmente las anteriores, pero también otras más, pues una persona que invierte sus muchas horas en un ejercicio de esclarecimiento que no somete a la hoguera tiene por vocación algo

16 Baste mencionar en este sentido la programación televisiva de los últimos tiempos, operando cambios en los gustos receptores al programar mayormente pasatiempos, concursos participativos o programas tertulia donde un anónimo ciudadano o espectador puede participar ofreciendo su opinión de incluso el asunto más nimio, pero lo curioso es que, a diferencia del distanciamiento impuesto décadas atrás al medio televisivo, en la actualidad se ha destapado una insistente búsqueda de lo íntimo exhibicionista, impúdico, desvergonzado hasta su espectacularización. Su aparente democratización de este medio de comunicación con la caída del aura sacralizada que poseía anteriormente hace pensar más bien todo lo contrario: la espectacularización de la intimidad a través de estrategias de desvío de los hechos predominantes y verdaderamente importantes de la sociedad. 
más, llámese el valor testimonial de sus escritos, la clarificación personal, la reflexión personal, la introspección ${ }^{17}$, la patentización del voyeurismo del sujeto (Mainer, 1994: 157), pero también -y sobre todo cuanto nos interesa-, a igual que todo texto, una práctica dialogica con la vida (véase a este respecto Lejeune, 1996: 58), cuya pretensión última si no es sucumbir en el propio acto de la vida de quien lo escribe, al menos pretende establecer un puente comunicativo con terceros, lectores de otros lugares, momentos o épocas para comprensión de la propia (época e incluso vida en su cotidianeidad por el valor que representa en sî), pero nunca quedarse en el círculo de la más absoluta privacidad: todo texto escrito y no publicado o leído no tiene existencia hasta que un lector lo re-produce con el sentido que le otorga su lectura ${ }^{18}$. Antonio Muñoz Molina se reafirma en esta opinión precisamente en el último artículo o capítulo o fragmento que compone el Diario del Nautilus, el que lleva por título «Dedicatoria»: «Miente quien dice no escribir para nadie, quien dice hacerlo para su solo placer o suplicio. Es posible que la literatura, como ha escrito Jaime Gil de Biedma, acabe pareciéndose al vicio solitario, pero yo prefiero imaginarla como un juego y una persecución regida por la cábala del azar.

17 Muchos son los motivos motores de esta forma de escritura. Alain Girard cree encontrar en el diario un método de conocimiento de uno mismo que concede la evidencia de la existencia humana: "Se espía a sí mismo a diario para intentar comprenderse tanto como conocerse, oponiendo a lo relativo y al sentimiento de evanescencia el único absoluto que le queda, el sentimiento de su propia existencia» (Girard, 1996: 37-8); en opinión cercana, Blanchot (1996: 51) ofrece los siguientes motivos: «se escribe para salvar la escritura, para rescatar su vida mediante la escritura, para rescatar su pequeño yo (las represalias que se toman contra los demás, las maldades que se destilan) o para salvar su gran yo dándole aire, y entonces se escribe para no perderse en la pobreza de los días, o, como Virginia Woolf, como Delacroix, para no perderse en ese tormento que es el arte, que es la exigencia sin límite del arte», También dirá Alain Girard (1996: 38): «Entre todos los textos escritos, ninguno puede informar mejor sobre la imagen del yo que los escritos en primera persona». Caballé (1995: 51) ve en el diario íntimo «una mayor espontaneidad en la exteriorización del yo». Por otra, hay quienes consideran al diario como un arma para efectuar un ataque pertinente a terceros, una forma de restituir la concepción de un yo que se cree desviada o restaurar opiniones tergiversadas. Su respuesta puede ser tan rápida que incluso en ese sentido Didier (1996: 41) llega a decir que puede sustituir al tradicional «panfleto».

18 Melo Miranda, apoyándose en Rousset, se reafirma en la consideración de la escritura diarista como esencialmente privada, de lo cual deduce que ello excluye todo pacto entre autor y lector, bien que conceda del mismo modo que hace el francés grados de apertura respecto a una oportuna concertación que se lleva entre manos el autor con el lector (Melo Miranda, 1987: 34). Nosotros, evidentemente, a este respecto no lo vemos del mismo modo. Melo Miranda problematiza en este mismo lugar una serie de cuestiones complejas y problemas que atañen al diario: afirma entre otras cosas que narrador y lector son la misma figura, al no trascender su lectura de no ser que se realice con una publicación póstuma, lo cual no creemos cierto del todo al menos sin sus pertinentes matizaciones. 
Uno escribe y aguarda, uno tiende al lector su cita, su celada de palabras asiduas, minuciosamente lo inventa...» (Muñoz Molina, 1986: 157). El diario sin el lector que le construya su sentido, del mismo modo que todo discurso, no es nada. En ese sentido se nos hace realmente difícil suscribir la segunda parte de la opinión de José Muñoz Millanes (1996: 137): «Un diario se presenta como el registro minucioso del trato de un escritor con sus obsesiones y deseos más privados, por lo que, en principio, tiende a excluir un destinatario que no sea el propio autor». Cuando menos a priori, no creemos que lo que marque la escritura del diario sea en cualquier caso la exclusión de un destinatario por cuanto hemos dicho, y menos bajo las leyes que rigen la actualidad de esta escritura en la fase del capitalismo tardío en que vivimos. En muchos de los casos, el objetivo de la escritura de diarios es recuperar la identidad a causa de multitud de hechos: el ser humano en plena evolución por ejemplo en la siempre problemática etapa de la adolescencia; la crisis de identidad que vive la sociedad con el advenimiento de la modernidad, que a su vez podría ser una posible explicación del aumento de este tipo de prácticas escriturales. Caballé (1995: 55) piensa que es ésta la más común de las causas de la escritura dẻ diarios: bien por la crisis evolutiva del ser humano o bien por la crisis del medio en que se desenvuelve el adolescente y con el que colisiona de continuo.

Gran parte de los diaristas aquí tratados tienen una vocación de compartir lo escrito en el propio diario con el lector asiduo (frente a cuanto piensa Melo Miranda: véase nota 18), hasta el punto de que muchos datos quedan enmascarados por iniciales o incógnitas $(\mathrm{X})$ que claman al anonimato, sobre todo los nombres propios de aquellas personas cercanas que pudieran sentirse identificadas en la lectura, dada la cercanía en el tiempo y la presencia en la vida cultural española, lo que da mayor noción de vocación de ese servicio hacia terceros que es la lectura de un diario ${ }^{19}$.

19 Así encontramos innumerables ejemplos de esta vocación velatoria como los que siguen publicados en un muestrario de diarios en el monográfico dedicado al diario íntimo en la Revista de Occidente. Bernardo Atxaga escribe: «Llamo a A.» (1996: 161); Julia Escobar: «conversación con S.», «Creo que P. ...» (1996: 170), «la velada pasada con MB.» (1996: 171); Laura Freixas escribe en su propio diario: «Almuerzo con X.» (1996: 176), «Almuerzo con Z.» (1996: 177), «W.» (1996: 178), e incluso: «por pertenecer al periódico A, le ningunean en los periódicos B, C y D.» (1996: 176); José Carlos Llop escribe enigmáticamente: «la casa que ha alquilado X» (1996: 190); Gustavo Martín Garzo, por su parte: «El asombro de V.» (1996: 195); Justo Navarro: ««Me alegro de verlo, Z.»» (1996: 217), «Hablo por teléfono con Y.» (1996: 220); 
El lector en muchos de los casos pretende, con los lectores de diarios ajenos, encontrar los detalles de autores que admira o que le son accesibles (según las estrictas leyes del mercado) para conseguir un conocimiento mayor de su persona que dé luz a algunos aspectos (oscuros) de su obra (Girard, 1996: 32). Lo cierto es que todo diario arroja una pluralidad significativa de la persona que se somete a su escritura (bien que ésta sea siempre - mayor o menormente - selectiva como hemos indicado).

Ello nos lleva a preguntarnos sobre una de las cuestiones más delicadas de esta modalidad escritural, como es la del sentido de una escritura medida por los parámetros de la circularidad, o cuando menos de los condicionantes impuestos por el ciclo temporal biológico. Julia Escobar confiere a la escritura íntima del diario el hecho de ser un verdadero laboratorio para su posterior desarrollo profesional como escritura, una especie de etapa de aprendizaje obligatorio o rodaje para hacer tablas ante una próxima profesionalización de rigor: «Volver otra vez a volcarlo todo en estos cuadernos, mi verdadera escuela. Aquí aprendí a vivir, aquí adquirí mi aplomo mundano, aquí es donde me estuve preparando para salir al mundo, como esos agentes secretos de las novelas de espionaje que les preparan en un monasterio budista o una escuela de alta especialización a actuar como inveterados burgueses o grandes aristócratas o cualquier otra cosa que, en principio, exige una vida de práctica continuada y contrastada. Un aprendizaje secreto y clandestino, esquizoide. Una fragmentación de la personalidad tan inverosímil que le mantiene a uno en el umbral de la más acrisolada locura» (Escobar, 1996: 169). Esta disociación de su personalidad al borde de la desviación psíquica le lleva a mantener profundas reflexiones consigo misma respecto a su persona y el lugar que ocupa el diario en su personalidad, hasta el punto de obtener la convicción de que determinadas experiencias recibidas directamente de la vida (por lo general compartidas, como la que alude) son más profundas que el ensimismamiento del diario: «¿No era yo más yo que en otras ocasiones, por ejemplo, cuando escribo aquí, en que creo ser absolutamente yo? Pues posible-

Juana Salabert utiliza las abreviaturas con harta frecuencia: «Hablé con G.» (1996: 228), «como decía el viejo M.» (1996: 228), «Esta tardenoche iré al cine, con E. y B.» (1996: 230), «no llego al extremo de G.» (1996: 230), «Hemos vuelto casi a las doce de casa de E.» (1996: 230), «J. lo hace tan bien...» (1996: 231), «vendrán A. y O. Quizás también Y.» (1996: 232), «A.M. siempre me da ánimos» (1996: 234), o el propio Trapiello que muestra una voluntad decidida por enmascarar nombres propios: «Me cuenta $X$ que...» (1996: 248), «Me ha telefoneado $X »(1996: 249)$, «Me dijo que se llamaba Magdalena F.M.» (1996: 255), «Según me asegura X.» (1990: 84). 
mente ayer fui totalmente yo misma para gran sorpresa de mí misma. Y me gustó» (1996: 171-2). Más adelante confesará con toda sinceridad el desdoblamiento practicado en su personalidad, donde se hallan diferentes prismas de su persona en plena convivencia tras haber alcanzado un equilibrio estable: «convive esa persona interior, retraída, solitaria, con un monstruo de vanidad y egocentrismo que me lleva muchas veces a hacer cosas en las que no me reconozco» (1996: 173). Esa otra persona con la que ha estado compartiendo la noche anterior con lo que se supone un diálogo sincero sobre temas que a ambas les preocupa como la literatura, poesía, etc., le lleva a sincerarse con ella y a declararle su obsesión por la escritura del diario, como base para afianzar su predisposición literaria, pero también como confesión íntima (hasta cierto punto, cuando ya hemos dicho la necesidad de blindar ciertos nombres propios), y lugar donde anotar y apuntar cuestiones con vocación de perdurar para cuando interese recobrarlos ${ }^{20}$. De cualquier modo, una frase posterior da la medida de la pujanza de este tipo de escritura en la autora cuando para ella el diario es el recuerdo de un presente que se desvanece, la memoria perpetua de las acciones en proceso: «la vida nos escribe; no tenemos más realidad que la plasmada en la escritura que es el instrumento más eficaz para perpetuar el recuerdo de lo hecho.» (1996: 173). Al hilo de esta reflexión nos viene la de Gustavo Martín Garzo sobre la labor del diarista cuando analiza la función de quien se somete a este tipo de escritura: «Vuelves a preguntarte por el sentido de continuar con estos cuadernos. Sobre todo a partir de tu sospecha, cada vez más arriagada, de que la razón que asiste a cualquier vida, su sentido último, no puede desplegarse a través de un ejercicio autobiográfico, de un movimiento confesional. Ese sentido tiene que ver con ciertos sucesos básicos, remite a un lugar al que la confesión nunca podrá acceder, porque sólo se expresa lo que se sabe, y la figura del que lo hace es siempre la figura de un usurpador, de aquel que ocupa el lugar de un otro escondido, relacionado con un secreto, un acontecimiento o una presencia que inevitablemente se desconoce» (1996: 196). Este trauma por el que atraviesa la confesión marca las limitaciones de un tipo de escritura que lleva inserta la paradoja de ser-

20 «Entonces le confesé mi «diaritis». No pareció entenderlo, más bien censurarlo, le expliqué lo que han supuesto los diarios para mí. Cómo, por un lado, me han servido de cantera para escribir y cómo, por otro, al mismo tiempo, me frenaban y desviaban. Y también de cómo, conforme más publico y escribo «para fuera», menos necesidad tengo de recurrir a ellos. Y es natural. Ahora sí se están convirtiendo en verdaderos diarios, es decir, en cuadernos de apuntes de lo que uno no quiere olvidar demasiado y de lo que no se puede decir demasiado alto ni a demasiada gente» (1996: 172). 
vir a los procesos psíquicos del ser humano pero que a menudo cae en las trampas de la complejidad de esos mismos procesos psíquicos. Del mismo modo que Julia Escobar, Martín Garzo llega a la conclusión de que cuanto en principio comienza como un ejercicio de autoclarificación personal acaba topándose con las barreras a las que le sale al paso el velo de la escritura en tanto material opaco que se las tiene que ver con la pluralidad de yoes que habitan en el seno de un ser humano. Martín Garzo llegará luego a una conclusión para él vital en tanto novelista cuando cree que la literatura es fruto de esta misma contradicción humana: «La verdadera literatura sólo puede surgir del esfuerzo por acoger ese secreto, por acogerlo y dejarlo hablar. Y, en tu opinión, en una literatura directamente confesional esto no es posible» (1996: 197). En el fragmento del diario de Carme Riera titulado significativamente «Notas de clase» (puesto que es el diario escolar de una profesora universitaria en la Autónoma de Barcelona), medita sobre su vida al hilo de la fechación diaria que establece el diario llegando a conclusiones verdaderamente trascendentales en el sentido rimbaudiano de desdoblamiento que impone la escritura de un diario: «...el día a día del acontecer de mi triple y hasta cuádruple condición: madre, esposa, hija, mujer. Cuántas máscaras, desdoblamientos, heterónimos de una misma persona. ¿Verdadera? Yo es, soy otra... La otra» (1996: 225). Luego añadirá que el sentido de ese diario es otro muy distinto (al disociativo de la personalidad), más conforme a la máscara que ha adquirido su persona en la vida privada: «Pero no, eso es para otro cuaderno. En éste, como celebración particular de cumpleaños —bodas de plata, iqué barbaridad!, con la enseñanza-, me propongo únicamente poner por escrito lo relativo a mi trabajo en la Autónoma, algo así como una prolongación del escolar emploi du temps» (1996: 225). Si el diario es la escritura de una identidad concreta temporalizada en un marco preciso, quizá eso es lo que lleva a Juana Salabert a declarar la variación de la personalidad con el avance de los años que hace percibirnos como diferentes a los que fuimos en el pasado: «No se crece, salvo en la mirada de los otros. Tal vez por eso yo quemé los diarios de ciertos años...» (1996: 228-9). Por su parte, José Jiménez Lozano cree ver en la escritura de su diario el testimonio para terceros de la travesía vital de una persona dedicada a los menesteres públicos de la escritura literaria, un recordatorio o acompañamiento fuera de la patente de una vida: « Ojalá que las pequeñas notas de estos «diarios» sirvan para acompañar a alguien a su vez, o, al menos, como dije en Los tres cuadernos rojos, les sirvan como un trozo de cuerda o de lacre, o un cabo de vela que se guarda en una caja. Esta es su finalidad exclusiva» (1996: 185). De 
modo parecido piensa José Carlos Llop cuando escribe en el fragmento de su diario que los «dietarios son una manera de subrayar el hecho de ser contemporáneos: esa maldición, que decía Borges» (1996: 190), una forma de constatar la existencia de una persona en un momento del tiempo concreto. Por su parte, Antón Tovar en su «Diario d'un vellido» declara la vocación plural de un diario, donde se registran pensamientos inconexos o tabla de salvación de ciertas personalidades que viven en una introspección reflexiva: «Un diario puede ser algo así como los pensamientos de Pascal, aunque no lleven fecha o como mi Diario sin datas, mío, claro que de menos valor o algo así como ese ruido sonoro y preocupante de Cesare Pavese» (1996: 243).

Eloy Sánchez Rosillo publica en 1981 el poemario que lleva por título Páginas de un diario; tres años después publica otro poemario titulado Elegías, con una clara estructura periódica; posteriormente, en 1989, reincide en esta fórmula literaria con un poemario que lleva por significativo título el de Autorretratos. Elegías está fechado entre 1980 y 1983, publicado un año más tarde, quedando patente la vocación explícita de diario que constituye el poemario en su conjunto. Todos los poemas del libro están fechados con exactitud en una «cronología de los poemas» elaborada por su autor al final del poemario, antecediendo al índice (Sánchez Rosillo, 1984: 63), sólo que la fechación es salteada y presenta la particularidad de no estar ordenada cronológicamente sino bajo el arbitrio particular del poeta, en el que el primer poema está elaborado el «7 de junio de 1983» y el segundo el « 20 de julio de 1983», pero el tercero el «9 de diciembre de $1980 »$, donde la fechación de todos los poemas comprende el abanico cronológico que abarca los años 1980 y 1983. El sujeto poético se presenta por lo general solo, en una actitud reflexiva o rememorando su infancia o adolescencia para dolerse del paso del tiempo, con paisajes muchas de las veces solitarios en que el propio protagonista pretende aislarse del resto de los seres humanos, alejarse a veces en pleno idilio con la naturaleza.

Diario de un poeta recién cansado (1985), de Jon Juaristi, emula el título juanramoniano para precisamente rendirle tributo, mediante una voluntad revalidada en posteriores entregas del poeta, enganchando con la tradición literaria española precedente, en este caso a partir del equívoco creado en la palabra «cansado» como gusta la poética de Juaristi. En el libro se crea un espacio de ficción bautizado como «Vinogrado» que no es más que un trasunto de su Bilbao natal, microcosmos o referente urbano al que remite continuamente la acción sobre la que planea 
una vocación de crítica en forma sarcástica. Pese a ser un poema coloquial, irónico e incluso a veces sarcástico, este libro lo más que tiene de diario es el título, bien que en algunas pretensiones se acerque, pero no acaba de conformarlo formalmente por cuanto no existen huellas fechadas de los poemas, ni apenas alusiones temporales concretas de los escritos, salvo varios poemas de forma más bien casual. El libro comienza con un poema titulado «Material de derribo», que lleva la indicación siguiente «(Para una poética)», el cual se corresponde con esa ficcionalización del espacio urbano donde ubica la acción, Vinogrado, o lo que es lo mismo, Bilbao. La escenificación de su ciudad en el espacio de la memoria enmarca perfectamente lo que será el conjunto del libro.

Lo que en un inicio fuera publicación semanal de artículos en el periódico El Ideal de Granada, bajo el título de Diario del Nautilus, entre septiembre de 1983 y finales de junio de 1984, posteriormente sería recopilado — dado su valor testimonial y el creciente despunte de un autor con una importante capacidad prosística- en 1986 en edición de la Diputación Provincial de Granada, con la incorporación del último artículo que atiende al nombre de «Dedicatoria», aparecido también en prẹnsa en septiembre de 1984. El motivo de la escritura es registrar y comentar testimonialmente sucesos de la vida cultural y social española e incluso internacional, en el momento en que se entrega su autor a la escritura. El título remite a las claras al viaje literario ficcionalizado por Julio Verne en el submarino del capitán Nemo llamado Nautilus, con lo cual el diario, al modo de los grandes aventureros y navegantes, es una necesidad de plasmar las vivencias de otro viaje, el vital de Muñoz Molina a lo ancho de la cultura cercana e instantánea en la España de su momento: «Pero ni siquiera en el Nautilus, que no es buque de guerra, sino refugio submarino contra las crudas afrentas de la realidad, está uno a salvo de que le maltraten sus recuerdos» (1986: 19). Los temas que aborda serán múltiples pero se registran pilares básicos que conforman el grueso posterior de su narrativa como son la memoria del ser humano, el mecanismo del olvido, el tiempo, la muerte y la vida, las fotografías salvadoras de la desaparición del hombre, todo ello narrado con una prosa altamente literaturizada, aun partiendo de datos captados de la realidad, con un trasfondo mitológico (mitos literarios, cinéfilos, pictóricos...), con el solapamiento de la realidad cotidiana en que vive su autor y de la que extrae la crónica narrada (fecundación in vitro de un amante fallecido, el funeral de Grace Kelly, la literatura olvidada de Max Aub, la conmemoración en 1984 del libro con esa fecha de Orwell...). Todos los artículos, ahora convertidos en 
capítulos de un libro, remiten claramente a la forma estructurada de un diario, aunque no fechado día a día, sino más bien con dataciones implícitas semanales - sometidas a la escritura en el periódico donde fueron publicadas - que aunque no contengan fechación explícita sí al menos los sucesos comentados nos dan pie a seguir el curso de la vida española por los acontecimientos que se narran, siempre teniendo como trasfondo la estructura que le otorga su autor (de diario) al modo de la escritura testimonial que llevara el capitán Nemo a bordo del Nautilus en sus peripecias submarinas, por cuanto las alusiones son constantes en un intento de emular la realidad de aquella ficción literaria: «Tal fortuna, que yo he envidiado incesantamente desde que en la infancia leí por primera vez las páginas de Julio Verne, les cupo a tres viajeros que fueron acogidos en el Nautilus en la madrugada de un día de 1866» (1986: 29). Este acogimiento al que hace referencia la cita es el mismo que practica en estas páginas el autor a una serie de hechos de la vida cotidiana aquí acogidos por la pluma de Muñoz Molina y diseccionados al calor de la actualidad vigente.

En La luz, de otra manera (1985-86) de Vicente Gallego la datación de todos los poemas forma parte de la textualidad conjunta del poemario, bien que atienda a una arbitrariedad puramente subjetiva la fechación. Comienza en «agosto, 26» con un sujeto poemático que se presenta absorto en la contemplación de la caída de la tarde y que se prolongará a lo largo del texto conjunto con una contemplación minuciosa de lo más nimio de las acciones cotidianas, con un afán remarcado por reflexionar en esa cotidianeidad en su apartamento, enumerando lugares comunes de su habitáculo: «casa», «lecho», «pasillo», «cama», «terraza», «diván», «cisterna» (1988: 11), pero que seguirá la prolija enumeración en otros poemas como en «septiembre, 20»: «nevera», «baño», «habitación», «calendario», «cortinas» $(1988,15)$. El espacio pertenece al ámbito privado en la mayoría de los poemas al ser su propio apartamento, y el tiempo también transcurre sin compartirlo con nadie, pero cuando se enmarca la acción en espacios abiertos, éstos suelen ser lugares aislados donde el sujeto prosigue su solitud: «con una desolación enorme que no entiendes» (1988: 11).

El gato encerrado, de Andrés Trapiello, son las páginas de un diario escrito en el curso de un año completo, 1987, no sólo porque el año queda adherido al título del interior, sino porque aun no habiendo fechación explícita del paso de los días, ni distribución correlativa de días a la manera de un diario clásico, la escritura se constituye en una hilaridad de fragmentos continuos - al modo de los días de un año- 
más o menos largos (a veces son anotaciones muy breves) fechados en 1987 en Las Viñas y Madrid, sin que cada fragmento se identifique con un día ni haya equivalencia alguna de cada fragmento con cada día del año («Llevaba un mes sin escribir en este cuaderno. Un mes. ¿A quién puede importarle?» [1990: 196]). La escritura es sumamente subjetiva, no sólo en cantidad de materias a tratar sino en la variedad de registros y material que lo integra, bien que una vocación de literaturización preside todo el libro. Trapiello somete a la ficción el diario que escribe, de tal modo que literaturiza sus propias experiencias manteniendo como sujeto narrativo a «A.T.» («o yo, A.T.» [141]), nunca aparece con su nombre propio, de hecho un indicio aparece al final del libro sobre la ficcionalización que aplica a su propia vida cuando alguien grita en voz alta su nombre, entonces es consciente de que le han desvelado y se ve obligado a finalizar el libro: «Me han descubierto [sus hijos]. Uno me pide que juegue al ajedrez. El otro quiere que le desate un nudo. $Y$ oigo mi nombre de nuevo, gritado desde abajo, y digo sí» (1990: 198). Precisamente en ese momento de afirmación identificativa acaba el libro. El texto es sumamente rico en sus aportaciones de material y reflexiones en torno a la modalidad escritural objeto aquí de estudio, por cuanto las pretensiones de Trapiello son las de servir al diario ficcionalizando su propia experiencia directa, pero desde la libertad absoluta: para ello se noveliza ${ }^{21}$ todo el relato con el discurso interrumpido de fragmentos que suelen ser cortos y sucesivos, pero donde el pudor íntimo o los asuntos personales particulares de quien escribe no se airean lo más mínimo; a veces se acerca, si bien siempre manteniendo una prudente distancia, porque es consciente de que está escribiendo para darlo a conocer (en el prólogo firmado en Madrid, abril de 1988, el autor recoge un diálogo mantenido con un tercero donde evidencia esta voluntad de ser entregado a la imprenta: «Le digo a X. que estoy corrigiendo un diario. / -Esta vez va en serio. / - ¿Lo publicarás? / -Si alguien me lo pide, sí. ¿Por qué no? / ¿Citas a la gente por su nombre? / -Casi nunca. No me atrevo.» $[1990,9])$. La voluntad de trascendencia del libro como tal es la empresa primordial de su escritura hasta el punto de que justo en el final del texto, el sujeto narrativo diga: «Leo la primera

21 El gato encerrado está publicado en la editorial Pre-Textos. Aparece en la parte superior de la cubierta el título del libro y debajo el nombre del autor. En el centro hay una ilustración de Picasso (Hombre con sombrero); debajo de la reproducción, a pie de cubierta, aparece el sello editorial y justo debajo aparece nítida la palabra "narrativa»: el libro está publicado para que no quepan dudas en la colección de narrativa de este sello editorial. Es una voluntad explícita - se supone que del autor, pero remarcado por el editor- de marcar los parámetros desde los que el lector leerá el libro: el pacto de ficcionalización se predetermina con el lector desde el propio umbral del texto. 
página de este cuaderno y miro el manuscrito de mi novela. Parece que he sido capaz. [...] Lo importante ha sido llegar al folio número doscientos doce y escribir la palabra FIN. Es un libro del que ya no quiero saber nada» (1990: 197-8), porque una vez acabado todo escrito sólo el lector le otorgará sentido, incluyendo - incluso- con estas comprometedoras palabras al diario en tanto modalidad creativa: todo texto sólo se construye, como dijimos anteriormente, con el lector. El diario posee la interesante particularidad de verter su autor en él hechos concernientes a su vida, pero sobre todo profesional, dejando de lado anécdotas que considera estrictamente privadas, personales por intrascendentes, sin el menor interés para un lector, y en cambio acentúa sus acciones en la vida cotidiana del mundo intelectual-literario, cultural y sus aledaños en los que vive y las actividades que ello fomenta. De hecho, el libro se puede considerar una especie de novela-río donde se vierte el caudal de la conciencia del propio escritor sin otro hilo conductor que el pensamiento, los aforismos, las sentencias de las que gusta, y cuestiones de su vida profesional donde todo está dosificado de tal modo que se estructura el material en forma de diario. Lo excepcional del caso es que Trapiello, autorizado diarista, se toma las molestias incluso de reflexionar sobre la propia labor del diarista y la función de todo diario, a veces en forma de aforismo: «A veces oímos que éste o el de más allá llevan un «Diario». Para algunos los «diarios» son las comisarías donde van a delatar o la checa donde presiden sus ejecuciones particulares. Algunos son más vanidosos y van más lejos: prohíben su publicación en tanto no pasen cierto número de años, como si guardaran los secretos de Fátima. Echarle la culpa a otros de lo que vemos nosotros parece una mezquindad» (1990: 27). Tales palabras ofrecen luz sobre la perspectiva adoptada en este diario, además de evidenciar los modos tradicionales de concepción de unà modalidad muchas de las veces autocomplaciente por el carácter público de su autor, pero considerada íntima y pudorosa. Más información sobre lo que considera el autor que es un diario nos la ofrece de forma literaturizada en la siguiente cita, al poner sobre la picota el carácter confesional y casi psicoanalítico de un diario, una necesidad de dialogar con ese desconocido que llevamos dentro, pero que a veces por represiones de carácter vario no se exteriorizan lo suficiente: «¿Qué son, pues, unas páginas de diario? Una taberna donde hay siempre un tabernero comprensivo con nuestras debilidades. Que nos escucha si le hablamos, que sabe guardar silencio si queremos estar callados. Esa clase de hombres que sabe decir incluso comprensivamente esa frase terrible: «Tenemos que cerrar»» (1990: 182). En otro momento, ya avanzado el diario, dirá en 
forma de sentencia, de las que echa mano a menudo: «No hay diarios mal escritos, sino vidas mal hechas (A propósito de la inarmonía de éste)» (1990: 116). En otro lugar dará cuenta, de forma incluso crítica pero no exenta de cierta ironización, del carácter de esbozo o apunte que adopta todo diario que se quiera tal (todo lo contrario que lleva a cabo Trapiello en El gato encerrado, por mucho que se moleste en disimularlo cuando se cuida repetidamente de corregirlo, depurarlo y escribirlo con logicidad y estructura): «(Releo este párrafo. Lo encuentro escrito en vizcaíno. Seguramente podría mejorarlo, pero no me apetece gran cosa. ¿Se entiende? Pues eso. Ya habrá tiempo para el estilo)» (1990: 173). Otras pistas del carácter aperturista de todo diario nos las da Trapiello de forma dispar, como cuando refiere que el tema de un diario es de lo más variopinto: «Todo es muy hermoso. No tengo tema ninguno para escribir. Recuerdo que ese mismo es el argumento de los diarios de Pepys, y sonrío. ¿Cuántas veces habré yo mismo repetido estas líneas aquí? Está uno, Pepys, para pocas fantasías» (1990: 197). No deja de ser curiosa la consideración llevada a cabo de modo general de que todo diario es un ejercicio literario propio de países desarrollados, cuando quizá las necesidades básicas de todo escritor están cubiertas y los temas se pueden privatizar hasta lo más hondo: «Los diarios son a la literatura lo que el yogur a la dieta: un privilegio de las naciones bien alimentadas» (1990: 25).

La novela de Juan José Millás, La soledad era esto, constituye a su manera otro ejemplo singular de diario al quedar éste instalado en la fábula: en la trama se introduce la escritura de un diario de la protagonista. La novela en sí es un artefacto que se construye a base de una intertextualidad ante un narrador ( $3 .^{\mathrm{a}}$ persona) que introduce (presenta) la historia en la primera parte y da cuerpo al relato de los sucesos, pero que pasa la iniciativa, en una segunda parte, a la escritura de ese diario que decide comenzar de pronto la protagonista ante los últimos sucesos acaecidos en su vida, que le llevan a decantarse por ese tipo de escritura nunca antes realizada. El texto está estructurado en lo que pudieran ser capítulos (seis en la primera parte, enumerados, en cuyo interior el cuerpo textual se segmenta a su vez en fragmentos). En la segunda parte, también continúan esos supuestos capítulos, sólo que sin enumeración y, sin fragmentación más que la introducción indiscriminada de lo que pudiera ser una narración en primera persona de la protagonista, con la inserción de su diario e intercalación de cartas o informes del investigador a quien encarga un seguimiento pormenorizado. La protagonista del relato, Elena, con 43 años cumplidos (idéntica edad a la del autor en el momento de la escritura), comienza la 
escritura de un diario motivada por el hallazgo del de su madre una vez desaparecida ésta. A partir de la muerte súbita de su madre, con la que apenas se trataba por diferencias de caracteres, Elena encuentra unos cuadernos en su casa (seis, de los que falta uno), comenzados curiosamente a la edad de 43 años: a partir de ahí las concomitancias entre ambas serán recurrentes y cada vez más palpables, hasta el punto de que la vida de Elena deviene paralela a lo que fue la de su madre (sin haberlo advertido hasta entonces la protagonista). En el cuaderno descubre muchos datos de sí, que ni siquiera sospechaba, pero que su madre vertió en forma de confesión en el diario, entre otras el ser considerada por ésta una «antípoda» suya («...aunque tengo cierta facilidad para ello, sobre todo desde que Elena, mi antípoda, se ha dado al alcohol y a las pastillas» [1990: 102], confesará su madre); conforme vaya leyendo los cuadernos concederá a su madre recién fallecida la consideración que en vida no tuvo: todo ello desencadenará la trama que, por otra parte, resulta sumamente atractiva, por lo que tiene de proceso de liberación de una mujer crecida en la contracultura del mayo del 68 y militante de izquierdas, casada con otro progre de pro, subido al carro del poder socialista y apuntado al pelotazo político, es decir, nuevo millonario merced al arrimo de los Ministerios respectivos con oscuros negocios. Elena, en ese período, al vivir una situación paralela a la de su madre respecto a una hija que en el presente de la historia tiene 22 años y que está casada, ha ido desencantándose de todo hasta el punto de que su vida constituye un verdadero vacío, pero precisamente por no haber hecho más que dejarse llevar por terceros que la han manejado a su antojo. Emprende una huida de su vida rutinaria como ama de casa con suficiente ocio como para sucumbir en una domesticidad que no le aporta nada ya y una adicción al hachís preocupante. La contratación de un detective de forma anónima para lo que en principio será un seguimiento de su marido, ante las conjeturas de una presunta relación amorosa con una amante, y su frialdad al certificar tal hecho, le llevan a no inmutarse, para luego crear el reto de que el detective la siga a ella misma y elabore informes subjetivos sobre y para ella, con los que acabará conociéndose mejor; ello, junto a la escritura personalizada de un diario que crece paralelo al de su madre, acabará por despertarle la conciencia suficiente como para romper de forma tajante con su pasado (separándose de su marido) y crearse una vida nueva donde su personalidad aflore alejada de posibles manipuladores, momento en que toma las riendas de su vida por primera vez. El atractivo de la novela - hasta el punto de singularizarla por ello- reside en cómo la escritura confesional de un diario es 
capaz de crear conciencia en un personaje sin esperanza alguna y que adoptará conciencia de subversión en ese proceso de aprehensión a través de las palabras del diario - pero también de las consecuencias que ello tiene: es decir, el descubrimiento de las posibilidades reales de su persona - por adquirir una actitud revolucionaria ante la vida, precisamente una persona que se las había dado en su juventud de militante izquierdista, pero crecida a la sombra de un marido corrupto apuntado a la especulación económica, a la sombra del poder socialista. La protagonista, Elena, recibe una primera impresión reveladora del diario hallado en casa de su madre: «aunque el diario era un tesoro al revés, el negativo de un tesoro, pero dependería de ella invertir esa imagen, convirtiendo los claros en oscuros y los oscuros en claros, como es en ese proceso fotográfico que nos devuelve al fin la verdadera imagen de una realidad pasada, muerta, pero con capacidad de actuación sobre nuestras vidas, sobre mi vida» (1990: 103-4). A partir de entonces decide comenzar el suyo propio, sin nunca haber tenido un tipo de experiencia semejante: «Comienzo estas páginas que ignoro cómo llamaré o adónde me conducirán a los cuarenta y tres años, es decir, un poco más allá del punto medio de lo que podría considerar una vida muy larga» (1990: 107); lo cual precisamente le llevará a tomar conciencia de su sujeto a través de la intimidad de la escritura: «Diversos acontecimientos personales de complicada pormenorización me han situado en los últimos tiempos frente a la posibilidad de controlar activamente mi existencia. Me encuentro en el principio de algo que no sé definir, pero que se resume en la impresión de haber tomado las riendas de mi vida. Es cierto que aún ignoro cómo se gobiernan y que tampoco sé en qué dirección las utilizaré cuando aprenda a manejarlas» (1990: 107); pero esta toma de conciencia vendrá incorporada en el proceso de escritura del diario: conforme éste se escriba, al tiempo que se construya la novela, surgirá un futuro para la protagonista. El diario se nos muestra como todo un mecanismo revelador para la protagonista (libertador de su conciencia alienada), pero también para el lector (constructor de la trama y sus sentidos). Pronto la protagonista toma conciencia de su condición: «Mi vida discurre apaciblemente entre la lectura de su diario [el de su madre] y la redacción del mío. A ello he de añadir el extraño placer que me proporcionan unos informes que yo misma he encargado realizar a un detective privado» (1990: 108). Los titubeos iniciales en las consecuencias del diario pronto se irán despejando, dando paso al desvelamiento de un enorme potencial (hasta entonces oculto) en torno a la identidad de su autora, al tiempo que aglutinadora de la identidad dispersa durante 
toda su vida, y por lo tanto en reconstructor de la personalidad: «Pese a la firmeza de mis propósitos, llevo varios días sin acudir a este diario y eso me proporciona la rara sensación de no existir. ¿Le pasaría lo mismo a mi madre? La idea del diario, desde que lo comencé, me ha invadido como una obsesión. Yo sé que un diario de este tipo es una suerte de mapa esquemático en el que se relatan los aspectos más sobresalientes de la propia vida. Sin embargo, en mi imaginación, el diario es la vida misma. Alguna vez leí algo acerca de quienes confunden el territorio con la representación del territorio (el mapa); tal vez eso es lo que me sucede, tal vez por eso tengo la impresión de no haber existido los días pasados» (1990: 115). A partir de entonces su existencia estará subordinada a la representación que de su vida lleve a cabo en un cuaderno en forma de diario: el mismo no sólo es capaz de clarificar su vida sino insuflársela; sin él ya no será posible la existencia; de hecho, ella existe porque el diario le otorga vida. La escritura del diario para Elena significa la continuidad del juego iniciado por su madre: la escritura de un diario es un intento consciente o inconsciente por comunicarse con su hija Mercedes de la que le separa el mismo trecho que en su momento le separó con su madre, del mismo modo que el de su madre por primera vez en su vida le está comunicando a ella: «Entonces encendí la luz, cogí uno de los cuadernos de mi madre y encontré un pasaje que me emocionó especialmente; parecía escrito para mí y para aquella noche, porque decía así» (1990: 117-8). El diario será un punto de referencia y anclaje (sujeción de un yo a la deriva) en ella, del mismo modo que lo fue en su madre: «Tampoco ella tuvo muchos puntos de referencia: el alcohol, el diario y su bulto» (1990: 128). Es más, funcionará a partir de entonces como una guía espiritual, la que quizás debiera haber tenido en su juventud y que no tuvo ${ }^{22}$. Asumida la necesidad de una toma de conciencia para rescatar los fragmentos de una vida, en la novela los dos diarios se entrecruzarán ${ }^{23}$ cómplices del mismo malestar, al tiempo que narración y diario se funden en el proceso de construcción de la novela: «Abro entonces uno de sus diarios y leo, como siempre, al azar: De

22 La confesión del diario constituye el hilo referencial de la vida: «me he acordado de lo que dice mi madre en su diario acerca de los cuartos de baño de los hoteles. Llevaba razón: son un lugar perfecto para hacer un pacto con la locura propia» (1990: 156).

23 Ambos diarios entran en un proceso de simultaneidad en el entrelazado: «Por cierto, me he traído el último cuaderno del diario de mi madre con intención de leer aquí su secuencia final. Llevo muchas semanas retrasando esa lectura $\mathrm{y}$, no sé por qué, pensé que el extranjero sería un buen sitio para llevarla a cabo. De manera que acabo esta frase y comienzo a leer» (1990: 156). 
entre todas las frutas amargas de la vida, la muerte no es, ni con mucho, la peor. Lo malo es vivir lejos de una misma» (1990: 128). En ese proceso de asunción de conciencia, su madre se desvela como la figura que de pequeña le cuadriculara todo su mundo para vivir de acuerdo a unos patrones rígidos, pero a partir de los diarios hallados será precisamente la que le permitirá romper con todo ese mundo ${ }^{24}$. Al final, el diario deglute todo tipo de material textual bien sean los informes periódicos que emite el detective, bien la carta incorporada que le envía su marido Enrique al hotel donde se halla instalada provisionalmente en espera de su nuevo apartamento; ella transmite (dicta al lector) la carta de su marido (quizá para que haya constancia futura de ella, y su hija llegue a reconstruir lo que ocurrió del mismo modo en que ella lo está haciendo con la vida de su madre), sólo que se ahorra insertar la despedida: «No incluyo la última frase, la de despedida, porque me suena a fórmula de misiva comercial» (1990: 170). Por fin ha sido capaz de romper con todo su pasado con la ayuda de su diario y esbozar un futuro que por ahora se ve nítido por la importante carga liberadora que tiene: «Estoy bien, en paz conmigo misma y. algo excitada por saber qué será de mi vida en los próximos años, cómo envejeceré, cómo nombraré lo que me atañe» (1990: 180). Para Elena, la vida entonces sí merece la pena, y por tanto el diario se puede cerrar al haber cumplido definitivamente su función emancipadora, certificadora de (la) vida: «Sentada en ella escribo estas líneas que quizá sean las últimas, por lo menos las últimas de mi vida anterior, la que clausuré en Bruselas al día siguiente de encontrarme con mi antípoda» (1990: 180-1).

Beatriz Miami, de J. A. Masoliver Ródenas, se puede tildar como un artefacto textual que adopta la forma de diario un tanto peculiar, con mucho de memorialismo y tanto más de retrato autobiográfico del propio autor. Bajo la estructura de un diario hábilmente camuflado se esconden los recuerdos autobiográficos -prolongados en su pertinente ficcionalización - del autor nacido en Barcelona en el año 1939 y que vivió el ambiente cultural y literario de la ciudad en su juventud de los años 60, cuando en Barcelona comienza a aflorar una generación que se ha dado en llamar «la Escuela de Barcelona», junto al encuentro de exiliados hispanoamericanos que configuran esa otra

24 Véase la frase: «mi madre me mostró el estrecho pasillo y las mezquinas habitaciones por las que debería discurrir mi existencia, pero al mismo tiempo me dio un mundo para soportar ese encierro o para hacerlo estallar en mil pedazos. Me dio todo lo bueno y todo lo malo al mismo tiempo» (1990: 131). 
generación de narradores llamada el boom latinoamericano. Todo el libro queda estructurado (aparecido en la colección narrativas hispánicas de la editorial Anagrama, su tono ficcionalizador así nos lo certifica: el relato fluctúa todo el rato entre la realidad vivida en el pasado de la adolescencia del protagonista y la prolongación en la ficción de máscaras que esconden a los protagonistas reales de la época) en una escritura en forma de anotaciones en un diario fechado, que a diferencia de Trapiello no dura un año natural sino un año entre el período cíclico de febrero de 1988 y febrero de 1989 , con anotaciones puntuales esporádicas conforme llegan, casi ninguna de ellas con hilazón lógica de continuidad.

El libro está estructurado en capítulos que pudieran corresponderse con cada uno de los meses, a la vez que éstos quedan fragmentados en días respectivos, si bien la caoticidad con que ordena el material crea en un inicio un efecto de extrañamiento en el lector que más tarde tomará el pulso del texto; estos fragmentos están precedidos por un número que viene a ser el día de ese mes en el que se ejerce el derecho a la escritura en el diario, bien que en numerosas ocasiones esté repetido, además de ser caprichosos los días en que se escribe en el diario, con una aleatoriedad absolutamente personal donde un mes como marzo sólo tendrá dos números que coinciden con el día 11 ambos y ninguno otro más, o mayo tenga dos días, 29 y 31 , pero que febrero de 1988 tenga registrado cuatro veces el día cinco y le sigan 6 7-7-16-20-26-27; o que esa caprichosidad se ejerza en julio del siguiente modo: 5-8-12-15-17-19-23-27; o que uno de los meses más completos tenga registrados los días del modo siguiente: 1-7-8-12-1819-20-20-21-21-21-21-21-21-22-23-24-25-26-27-28-29. El azar en la elección de los días preside el cuerpo textual, pero dentro de estos días el texto prosigue con su vocación fragmentaria hasta el punto de que todo él está organizado por anotaciones aisladas como si de escritura espontánea en un diario se tratara; esta organización textual llega a momentos de verdadera criticidad donde pueden aparecer fragmentos con fecha de un día bajo una sola y breve frase; así el día 8 de julio dice: «No la toquéis ya más: así es la fecha» (1991: 32). El resultado de tal cuerpo textual resulta difícil de encasillar dada la peculiaridad de la prosa y de la estructuración que practica su autor, donde el tiempo verbal más frecuente en el que se narran los sucesos es el pasado de la memoria, aunque de cuando en cuando regrese al presente del recuerdo (1988-89), pero sin esa importancia que tiene el escenario donde pretende focalizar toda la atención en el lector, durante los años 60 de su juventud; una de las claves en ese sentido nos la ofrece el pro- 
pio autor cuando anota en septiembre de 1988: «Espérame aquí que me voy un momento al pasado, aunque sólo sea para demostrarte que esto de diario nada» (1991: 46). Preside en esta voluntad la vocación de desmitificar el manido encasillamiento en el que se obcecan los críticos; el texto tendrá, pues, una vocación de revulsivo literario, acicate desestructurador del canon literario establecido y aceptado por antonomasia (en todos los sentidos), porque aquí nunca está claro si el conjunto textual es un libro de memorias, una autobiografía de la juventud del autor, un diario, el diario memorístico de un escritor, las memorias autobiográficas de un literato, o todo al mismo tiempo, por cuanto no importa la adscripción a un género, sino el propio resultado textual en sí, como nos dirá en un momento determinado: «No importa cuándo, esto no es una autobiografía; son memorias porque proceden de la memoria, es un diario porque día a día acuden los recuerdos a convivir con lo que me está ocurriendo entonces» (1991: 162). Ésa es la mejor perspectiva de la «novela». La memoria del autor es la pieza indispensable en este puzzle constructor del elemento privilegiado de la escritura de lo que pudiera ser su generación literaria 0 , al menos, sus compañeros de vivencias literarias en los 60 tal y como espacializa: «¿qué recordamos de lo que hemos perdido? Literalmente nada. Entonces trato de hurgar en la memoria, buscar allí cada uno de los objetos que he ido perdiendo y, generosa, protectora, la memoria los ha ido borrando todos. Nada. Como el oleaje que arroja objetos a la playa, allí los abandona y con la misma indiferencia los recupera» (1991: 116). La conclusión más evidente a la que se llega es que Masoliver Ródenas se erige por encima de cánones a los que encorsetar su escritura, para llevar a cabo una escritura que sea fiel a la complejidad de la memoria y su maleabilidad temporal y, más que llevar a cabo la escritura de un diario, pasa revista y reflexiona a su libre albedrío sin que quepan limitaciones por el tipo de escritura elegida: «Necesitamos rebelarnos contra nosotros mismos y ciertamente lo conseguimos. Pero al regresar a nuestro espacio de orden y rutina, nos entra una tremenda desolación, buscamos por todos los rincones de la casa, reconstruimos todo lo que hemos hecho durante el día y si es necesario tambiên durante el día anterior, volvemos a buscar, primero en los lugares más insólitos, luego en los más obvios, volvemos a pasear por las mismas calles y a recorrer cada uno de los locales, y finalmente se nos confirma la falta de honradez de nuestros semejantes y maldecimos a la execrable raza humana. Demasiadas pérdidas hemos sufrido como para seguir entonces escribiendo sobre ellas, escarbando en ellas» (1991: 116). Ésta parece ser la perspectiva más certera de la escritura 
de Beatriz Miami. Al final de la novela, el narrador nos da con la clave del relato cuando ve devastado el paisaje de su infancia y juventud: "Con el pie aparto los añicos como si fuesen añicos del recuerdo. ¡Cuánto escombro en el suelo de la memoria!» (1991: 218), «las fotos que testimoniaban instantes de vida, fragmentos de muerte» (1991: 222), el fragmento que abarca la temporalidad caprichosa de la evocación de Masoliver Ródenas segmentado en el período cíclico de un año a partir de febrero de 1988. Este tono que tiñe de dolor evocativo a los recuerdos del pasado tiene su explicación por la oscuridad de una época y una educación sentimental recibida de tal modo que les ha marcado, a los de su generación, para siempre: «A quienes les interesó como dolorosa y lírica evocación de la infancia, les va a decepcionar el agresivo vacío sentimental» (1991: 212).

En el libro no sólo se recupera una etapa vital importante como es la adolescencia de un sujeto, sino que además no se detiene la escritura en el proceso de identificación personal, sino que va más allá centrando la perspectiva en el proceso cultural, político, social que se vive en Cataluña bajo el franquismo tardío, una época cargada de represión y opresiones que marcará la vida de los futuros intelectuales que comparten protagonismo en la novela, además de en la sociedad española. Es el retrato de una generación intelectual, pero que lleva adherida una fuerte carga de rencor de la que el protagonista no pretende disimular lo más mínimo: «Trato de recordar cuándo empecé a detestarle. Descubro que simplemente nunca me cayó bien» (1991: 206), dirá indisimuladamente de Paco Pobre, un personaje que comparte el mismo ambiente que el del protagonista.

Por otra, este discurso practica una transgresión continuada de toda clase de reglas (sintácticas, semánticas, fonológicas, tabúes...). Es una escritura en forma de collage donde se recopilan esbozos de ideas, sentencias, apuntes en lenguaje espontáneo y juegos audaces de palabras, cartas insertadas a terceros (1991: 12), anotación de diálogos llevados a cabo con otros bajo la particularidad de no seguir ningún tipo de reglas de notación al respecto ( $¿$ Era una enfermedad?, «¿Enfermedad? ¿Cuál enfermedad?», dijo Fuster Dallas. «La única enfermedad que tiene es esa picha tan ridícula.» «O sea - logiqueó Fenollosa-, que como no tiene picha no tiene enfermedad» [1991: 17]; en otros momentos, el diálogo se ciñe más a la convención, pero literaria o periodística: «P. ¿Cree en la vida? / R. Por supuesto creo en la vida: estoy en ella. / P. Pero usted tiene fama de pesimista. / R. Soy lo que podría definirse como un pesimista radical. Un pesimista de izquier- 
das, si este término no lo hubiese desprestigiado tanto la gente de izquierdas» [1991: 125]), «consejos » (1991: 22), «poemas propios y ajenos » $(1991: 24,96,97)$, pensamientos, apreciaciones, chistes («Era un tío tan catalán, tan catalán, tan catalán, que a pesar de que el pan no le gustaba mucho se comía todos los días cuatro barras» [1991: 150]). Todo ello siempre narrado desde una primera persona que preside el relato, a excepción de una primera del plural cuando comparte vivencias con amigos o conocidos.

El autor se inmiscuye en la historia con nombre propio, o descripciones vagas para aportar testimonio al carácter autobiográfico del relato antes comentado: « $i Y$ no recuerda a Roberto, a Masoliver?», dirá alguien en un momento determinado. Otras veces se describe del siguiente modo: «Soy un ser ligeramente alto, y él era claramente bajo, casi un enano: no había crecido nada desde entonces. No sé si soy fuerte porque no lo he probado nunca, pero soy cobarde. Siempre me ha parecido que los huesos se rompen como la madera y en los días de nieve no salgo de casa. Detesto a los valientes. Nací para la retaguardia y para la deserción. Pero dicen que los Capricornios de setenta kilos, metro ochenta y pico y cuarenta y tres de calzado son, además de melancólicos adictos a los horóscopos, gente de precisa intuición» (1991: 60). En otros momentos, la identificación viene dada a través de una ironía sutil al insertarla el propio autor como crítico: «Ella levantó la mirada de Los cuadernos del Norte donde había un interesante artículo de Masoliver Ródenas (personaje que había asumido bastante torpemente su marido unos diez años atrás) sobre El hijo adoptivo» (1991: 87). Al final del libro ironiza sobre la propia aparición del mismo en el ambiente cultural español: «Todos estos comentarios surgen a propósito de un nuevo e igualmente desconcertante libro de Masoliver, Beatriz Miami, publicado a todo color por la misma editorial que estuvo a punto de quebrar tras la publicación de Retiro lo escrito[... ] Nuevo riesgo porque el autor es el mismo e igualmente minoritario: es un reincidente» (1991: 211). Y poco antes ironiza sobre el lugar que ocupó cada intelectual en el momento más delicado de la transición, cuando el golpe de Estado: «Preguntar con sorna difamatoria que dónde estaba el patriota Macholiver el 23 de febrero de aquel año es mucho y muy mal preguntar. Cada uno hace lo que puede los 23 de febrero, día de San Policarpo. Sugerir, como hace él, que Ródenas odia a la patria porque odia a la familia y que odia a la familia porque sólo se ama a sí mismo y a Castaluna carece de fundamento» (1991: 211). 
Llegados a este punto, constatamos que la escritura autobiográfica de los diarios aquí contemplados se presta a una variedad de motivos tan dispares como lo son también el amplio abanico de temas abordados en ellos, donde caben toda clase de reflexiones, en especial las más cotidianas que conciernen a un ámbito concreto de actuación del protagonista, a un microcosmos en el que se desenvuelve bien que éste sea el de la literatura incluso nacional, en ciertos escritores conocidos, hasta las costumbres cotidianas y diarias de casi todos, con una cierta propensión al confesionalismo en muchos; en otros, derivada ésta hacia la soledad, por no mentar la pasividad que fomentan ciertas reflexiones en torno a la propia actuación de ciertos sujetos representados en los diarios. Todo ello, contemplado, las más de las veces, y ésta es una de las características grosso modo más certeras en un lenguaje que suele ser fragmentario y con una escritura que abusa en muchos casos de la instantaneidad en su forma de plasmar ideas (sobre todo en la modalidad poética), mediante una forma de remarcar la temporalidad muy apta para esta modalidad discursiva cuando se trata de dar a conocer momentos muy cercanos al de la escritura, prácticamente indeslindables y por lo tanto en un pasado próximo por no decir presente. En muchos de los casos esta escritura evidencia a través de su reflexividad una noción de reiteratividad de la acción que conlleva la abulia vital ${ }^{25}$. Los motivos finales por los que se desprende este tipo de escritura, a juzgar por sus características entrevistas, suelen ser también dispares, desde una reflexión cotidiana que sólo atañe al ámbito de quien escribe sin mayor trascendencia social, pasando por reflexiones existencialistas a raíz de un tipo de vida, hasta la reflexión en torno al ámbito personal o contextual, e incluso al ámbito profesional cuando su escritor cree que los datos vertidos tienen algún tipo de trascendencia social, siguiendo por una reflexión de la sociedad inmediata en la que vive quien escribe, las formas políticas que se dan, así como económicas y sociales, hasta escrituras que, desde la ficción, inciden en la cotidianeidad que vive el ser humano en la España de finales de milenio en el contexto global, para a partir de ahí pretender trascender ese núcleo de problemas íntimos que en consecuencia no hacen más que manifestar las carencias del ser humano con el fin de proponer alternativas constructivas que aporten algo a la sociedad en que se viven esas formas concretas de cotidianeidad. En ese sentido, parecen certeras las palabras de Roland Barthes referidas en un supuesto libro a medio camino entre la experiencia autobiográfica y

25 Por ejemplo, cuando dice: «todo de nuevo aquí mismo repitiéndose» (Gallego, 1988: 47), confiesa el sujeto poético de La luz, de otra manera al final del libro. 
el diario, donde a raíz de este último afirmará el contenido narcisista (?) de todo diario, si bien nunca llega a caer en cuanto constata, pues en nada le interesa ese aspecto lastimero de toda vida que a resultas sólo da cuenta de la privacidad de un sujeto sin más, cuando a nadie más sino a él le interesa esa endogamia ególatra de problemas intrascendentes, al fin y al cabo (en lo referente a un público lector genérico): «Producción de mis fragmentos. Contemplación de mis fragmentos (corrección, pulitura, etc.). Contemplación de mis desechos (narcisismo)» (Barthes, 1975: 104). Lo cual evidencia o cuando menos nos hace pensar que las palabras con las que se construye todo discurso diarístico no dan cuenta de una construcción imaginaria (donde el referente pertenece a otra dimensión más allá del lenguaje); al calor del fervor estructuralista, la intimidad no es un estado del alma o una forma de afrontar la relación del individuo consigo misma, sino cuando menos una cuestión de construcción del lenguaje, una estrategia sígnica con la que definir los modos en que el individuo revierte sobre sí mismo su relación con el mundo. En un fragmento de su supuesta autobiografía Roland Barthes por Roland Barthes, titulado «Empleo del tiempo», narra -uno de los pocos indicios narrativos de su vida estrictamente privada en el librolo que realiza a lo largo de un día de vacaciones desde que se levanta hasta que se acuesta, para acabar refutando el interés de lo narrado y dudando de su trascendencia, probablemente para ponerlo en evidencia: «-Nada de esto tiene ningún interés. Aún más: no sólo uno marca su pertenencia a una clase sino que además hace de esa marca una confesión literaria cuya futilidad ya no es percibida: uno se constituye fantasmáticamente como «escritor», o, peor aún, uno se constituye» (Barthes, 1975: 89). El acto de constitución de un sujeto, de nuevo incluso en este discurso como en todo aquel que se lleve por medio del lenguaje es, como diría Paul de Man, ilusorio; es decir, llevado a cabo bajo la potestad del signo lingüístico.

Como quiera que no podemos quedar ajenos a las manifestaciones discursivas de la sociedad actual, se puede afirmar que ha habido una permeabilidad de lo púdico, al tiempo que se ha abandonado una cierta ingenuidad primeriza en su modo de afrontar lo subjetivo, más alejada de los convencionalismos sociales antaño aceptados, pero con nuevas formas más irreverentes. El diario, hemos visto, es utilizado por cada cual de maneras muy diversas y en diferentes contextos (véase, entablar una dialéctica con otras ideas y otros textos del momento, autojustificación personal, debate sojuzgador en/a la época del autor, aportar al debate intelectual o cultural el granito de arena particular...), pero también para ver cómo la complejidad del sujeto occidental --en 
nuestro caso- se inserta en el todo social al que pertenece y del que es capaz de problematizar una serie de cuestiones vigentes en la sociedad en la que vive instalado. Ese modo de escritura, en el que se privilegia lo público sobre una cierta privacidad teñida de una idea romántica del mundo y arrumbada de la historia, donde cuanto se devuelve al lector tiene el decoro suficiente como para problematizar una serie de conflictos que le son familiares en el ambiente o el contexto de su misma sociedad, sin la tomadura de pelo de hacerle participar en la coartada de una vida privada que ya a nadie puede interesar como tal, al no aportar nada al conjunto de la sociedad, y menos al receptor de tales textos, es el que merece el beneplácito de un lector que se mide de tú a tú con el sujeto emisor de tales textos, por cuanto no sólo construye el suficiente presente como para amarrar históricamente, sino sobre todo el futuro necesario para que tal fenómeno linguístico adquiera relevancia bajo la mirada atenta del lector. En ese sentido, decimos, lo púdico perfectamente recobra su sentido como una forma de intervención pública, constructiva, dialéctica y operativa a todos los efectos.

\section{Referencias bibliográficas}

BARTHES, Roland (1975). Roland Barthes por Roland Barthes. Barcelona: Editorial Kairós, 1978.

BLANCHOT, Maurice (1996). «El diario íntimo y el relato». En El diario íntimo. Fragmentos de diarios españoles (1995-1996). Revista de Occidente 182-183, julio-agosto, 47-54. [Cap. extracto de El libro que vendrá, Caracas: Monte Ávila Editores, 1969.]

Bou, Enric (1996). «El diario: periferia y literatura». En El diario intimo. Fragmentos de diarios españoles (1995-1996). Revista de Occidente 182 183, julio-agosto, 121-135.

CABAllÉ, Anna (1995). Narcisos de tinta. Ensayo sobre la literatura autobiográfica en lengua castellana (siglos XIX y XX). Málaga: Megazul.

- (1996). «Ego tristis (El diario íntimo en España)». En El diario íntimo. Fragmentos de diarios españoles (1995-1996). Revista de Occidente 182-183, julio-agosto, 99-120.

Castilla del Pino, Carlos (1996). «Teoría de la intimidad». En El diario intimo. Fragmentos de diarios españoles (1995-1996). Revista de Occidente 182-183, julio-agosto, 15-30.

Catelli, Nora (1996). «El diario íntimo: una posición femenina». En El diario intimo. Fragmentos de diarios españoles (1995-1996). Revista de Occidente 182-183, julio-agosto, 87-98. 
DIDIER, Béatrice (1996). «El diario ¿forma abierta?» En El diario íntimo. Fragmentos de diarios españoles (1995-1996). Revista de Occidente, 182183, julio-agosto, 39-46. [Versión abreviada de la conclusión a Le journal intime, París: Presses Universitaires de France, 1976.]

FREIXAS, Laura (1996). «Auge del diario ¿íntimo? en España». En El diario íntimo. Fragmentos de diarios españoles (1995-1996). Revista de Occidente 182-183, julio-agosto, 5-14.

GENETTE, Gérard (1991). Ficción y dicción. Barcelona: Lumen, 1993.

GIRARD, Alain (1996). «El diario como género literario». En El diario íntimo. Fragmentos de diarios españoles (1995-1996). Revista de Occidente182183, julio-agosto, 31-38. [Versión abreviada de la introducción a Le journal intime, París: Presses Universitaires de France, 1963.]

LeJEUne, Philippe (1971). L'autobiographie en France. París: Armand Colin. - (1996). «La práctica del diario personal: una investigación (19861996)». En El diario intimo. Fragmentos de diarios españoles (19951996). Revista de Occidente182-183, julio-agosto, 55-75.

MAINER, José-Carlos (1994). De postguerra (1951-1990). Barcelona: Crítica. MARf, Antoni (1994). Formes de l'individualisme. València: Tres i Quatre Edicions.

MAY, Georges (1979). L'Autobiographie. París: PUF, 2. ${ }^{\text {a }}$ ed. mars 1984.

MElo Miranda, Wander (1987). Contra a corrente; a questão autobiográfica em Graciliano Ramos e Silviano Santiago. São Paulo: Tesis Doctoral Universidade de São Paulo, 1987.

MuÑoz MillaNes, José (1996). «Los placeres de los diarios: el caso de Marià Manent». En El diario intimo. Fragmentos de diarios españoles (19951996). Revista de Occidente 182-183, julio-agosto, 136-146.

NEUMANN, Bernd (1970). La identidad personal: autonomía y sumisión. Buenos Aires: Editorial Sur, 1973.

POPE, Randolph D. (1974). La autobiografía española hasta Torres Villarroel. Frankfurt: Peter Lang/Herbert Lang, Bern.

WeINTRAUB, Karl J. (1991). «Autobiografía y conciencia histórica». En Anthropos, Suplementos 29, 18-33.

\section{Diarios}

ATXAGA, Bernardo (1996). «Diario [fragmentos]». En El diario intimo. Fragmentos de diarios españoles (1995-1996), Revista de Occidente 182-183, julio-agosto, 159-162.

Escobar, Julia (1996). «Diario [fragmentos]». En El diario íntimo. Fragmentos de diarios españoles (1995-1996). Revista de Occidente 182-183, julio-agosto, 168-174.

FreIXAS, Laura (1996). «Diario [fragmentos]». En El diario íntimo. Fragmentos de diarios españoles (1995-1996). Revista de Occidente 182-183, julio-agosto, 175-180. 
Gallego, Vicente (1988). La luz, de otra manera. Madrid: Visor.

Jiménez Lozano, José (1996). «Diario [fragmentos]». En El diario íntimo. Fragmentos de diarios españoles (1995-1996). Revista de Occidente 182183, julio-agosto, 181-186.

JUARISTI, Jon (1994). Mediodía (1985-1993). Granada: Comares.

LloP, José Carlos (1996). «Diario [fragmentos]». En El diario íntimo. Fragmentos de diarios españoles (1995-1996). Revista de Occidente 182-183, julio-agosto, 187-193.

Martín Garzo, Gustavo (1996). «El cuarto cerrado». En El diario íntimo. Fragmentos de diarios españoles (1995-1996). Revista de Occidente 182183, julio-agosto, 194-202.

Masoliver Ródenas, Juan Antonio (1991). Beatriz Miami. Barcelona: Anagrama.

Millás, Juan José (1990). La soledad era esto. Barcelona: Ed. Destino, 2." ed., 1995.

Muñoz Molina, Antonio (1986). Diario del Nautilus. Madrid: Diputación Provincial de Granada-Mondadori, 1989.

NAVARro, Justo (1996). «Diario [fragmentos]». En El diario íntimo. Fragmentos de diarios españoles (1995-1996). Revista de Occidente 182-183, julio-agosto, 216-220.

RIERA, Carme (1996). «Notas de clase». En El diario íntimo. Fragmentos de diarios españoles (1995-1996). Revista de Occidente 182-183, julio-agosto, 221-226.

SALABERT, Juana (1996). «Diario [fragmentos]». En El diario íntimo. Fragmentos de diarios españoles (1995-1996). Revista de Occidente 182-183, julio-agosto, 227-235.

SÁNCHEZ Rosillo, Eloy (1984). Elegías. Madrid: Trieste.

Tovar, Antón (1996). «Diario d'un vellido (Diario de un viejecito)». En $E l$ diario intimo. Fragmentos de diarios españoles (1995-1996). Revista de Occidente 182-183, julio-agosto, 242-246.

Trapiello, Andrés (1990). El gato encerrado, Valencia: Pre-Textos.

- (1996). «Diario [fragmentos]». En El diario intimo. Fragmentos de dia rios españoles (1995-1996). Revista de Occidente 182-183, julio-agosto, 247-256. 